\title{
HEALTH MAINTENANCE ORGANIZATIONS AND THE ROLE OF ANTITRUST LAW
}

\author{
PhILIP C. KISSAM*
}

I. INTROdUCtION.................................. 488

II. Initial Considerations ........................ 490

A. Competitive Characteristics of HMOs ............ 490

B. The Historical Confrontation .................. 492

1. Private Restraints: The Early Antitrust Cases..... 493

2. Public Restraints: Restrictive Use of State Laws .. 495

III. Private Anticompetitive Obstacles ${ }^{-\ldots . . . . . . . . . . . . . ~} 499$

A. The Interstate Commerce Question ................ 499

B. Professional Restrictions ...................... 503

1. Boycotts and Refusals to Deal ................ 503

2. Conscious Parallelism...................... 508

3. Protected Communications .................. 510

4. General Impact of Professional Restrictions ....... 512

C. Price Discrimination by Hospitals ................ 512

1. The Application of Price Discrimination Law .... 514

2. Parker v. Brown Defenses .................. 516

D. Restrictive Activities by Insurance Companies ........ 520

1. The Showing of Market Power ............... 521

2. Refusals to Deal.......................... 523

3. Anticompetitive Pricing .................... 525

* Professor of Law, University of Kansas School of Law; LL.B. 1968, Yale University. As will be evident from frequent references in the text and footnotes, I owe a substantial intellectual debt to Professor Clark C. Havighurst of Duke University School of Law for many of the ideas and arguments employed in this Article. I also am indebted to Professors Mark Pauly, Northwestern University, and Sidney Shapiro, University of Kansas School of Law, and to Mr. Joseph Sims, Antitrust Division, United States Department of Justice, for their comments on a draft of this Article.

THE FOLLOWING CITATIONS WILL BE USED IN THIS ARTICLE:

Bureau of Economics, Federal Trade Commission, The Health Maintenance OrGANIZATION AND ITS EFFECTS ON COMPETITION (1977) [hereinafter cited as FTC RERORT];

L. Sullivan, ANTrTrusr (1977) [hereinafter cited as L. SullivaN];

Havighurst, Health Maintenance Organizations and the Market for Health Services, 35 LAW \& CONTEMP. Pros. 716 (1970) [hereinafter cited as Havighurst, HMOs];

Kissam \& Johnson, Health Maintenance Organizations and Federal Law: Toward a Theory of Limited Reformmongering, 29 VAND. L. REv. 1163 (1976) [hereinafter cited as Kissam \& Johnson, Federal HMO Laws];

Kissam \& Johnson, State HMO Laws and the Theory of Limited Reformmongering, 25 KAN. L. REv. 121 (1976) [hereinafter cited as Kissam \& Johnson, State HMO Laws]. 


\section{Defensive HMOs: Monopolization and Joint Venture} Issues .................................... 527

5. The McCarran-Ferguson Exemption ............ 529

6. Primary Jurisdiction and Implied Immunity Defenses ................................ 537

IV. Conclusion ................................... 539

\section{INTRODUCTION}

Health maintenance organizations (HMOs) may be defined as institutions that both insure and provide health care services to a voluntarily enrolled population in exchange for prepaid per capita payments. ${ }^{1}$ HMOs have become a small but viable sector of the medical economy and are potentially significant vehicles for controlling health care costs. ${ }^{2}$ This form of organization appears capable of providing medical care more efficiently than fee-for-service providers and insurers ${ }^{3}$ and should therefore exert significant competitive pressure on the fee-forservice sector. ${ }^{4}$ HMOs also may threaten noneconomic interests of feefor-service physicians because of the HMOs' different goals and innovative methods of delivering health services. ${ }^{s}$ These factors, together with the history of organized medicine's opposition to HMOs, ${ }^{6}$ suggest

1. See Institute of Medicine, National Academy of Sciences, Health MainteNANCE ORganizations: Toward a FaIR Market Test 2-3 (1974).

2. Havighurst, Controlling Health Care Costs; Strengthening the Private Sector's Hand, $1 \mathrm{~J}$. HEALth Pol., POL'y \& L. 471, 489 (1977); see FTC REPORT; Havighurst, HMOs; Note, The Role of Prepaid Group Practice in Relieving the Medical Care Crisis, 84 HARv. L. Rev. 887 (1971). The first HMOs, as defined in the text accompanying note 1 supra, were established in 1929. See W. Maccoll, Group Practice and Prepayment of Medical Care 20-21 (1966); Health Services administration, U.S. Dep't of Health, Education and Welfare, Health MainteNANCE ORGANIZATIONS: SUMmarY OF FY 1975 ANNUAL REPORT 1 (1975). By 1965 there were approximately $20 \mathrm{HMOs}$ serving 1.5 million subscribers, $i d .5$, and today there are more than 170 HMOs serving over 6 million people. Letter from Frank H. Seubold, Director, Division of Health Maintenance Organizations, HEW, to Philip Kissam (July 25, 1977).

3. For a discussion of the theoretical reasons for HMOs' greater efficiency, see Auger \& Goldberg, Prepaid Health Plans and Moral Hazard, 22 PuB. PoL'y 353, $356-58$ (1974). For summaries of empirical studies comparing HMOs' economic performance with that of the fee-forservice sector, see Donabedian, An Evaluation of Prepaid Group Practice, 6 INQUIRY, Sept. 1969, at 3; Roemer \& Shonick, HMO Performance: The Recent Evidence, 51 Milbank MeMorial FUND Q. 271 (1973).

4. See FTC REPORT 16-138; Havighurst, HMOs 743-47; Havighurst, Speculations on the Market's Future in Health Care, in Regulating HeALth FaCilities Construction 249, 256-65 (C. Havighurst ed. 1974); J. B. Christianson, Do HMOs Stimulate Competition? (1978) (available from Interstudy, P.O. Box S, Excelsior, Minn. 55331).

5. On the different nature of HMOs' goals and methods and the ways in which noneconomic interests of fee-for-service physicians may be threatened by them, see text accompanying notes 1617 infra.

6. See Kessel, Price Discrimination in Medicine, 1 J.L. \& Econ. 20, $32-42$ (1958); Rayack, Restrictive Practices of Organized Medicine, 13 ANTITRust BuLL. 659, 677-97, 711-12 (1968); Note, supra note 2, at 954-75. 
that HMO development may continue to face a variety of anticompetitive restraints from fee-for-service physicians and their allies. ${ }^{7}$

The purpose of this Article is to examine the role that antitrust law might play in protecting HMO development from unfair resistance by fee-for-service interests. Part II of the Article is prologue, which examines the basic nature of the HMO threat to others and the history of conflicts between HMOs and the fee-for-service sector. Part III analyzes the jurisdictional and substantive issues that will be raised by antitrust litigation designed to protect HMOs from anti-competitive behavior. The consistent theme of this analysis is that antitrust law appears to have a useful but limited role to play in protecting HMOs from such behavior. Significant limits appear likely because of three related factors. The first is the intricate set of economic and political relationships among health care providers and insurers, to which all HMOs, but particularly newer and smaller ones, are bound. These relationships may make much anti-HMO behavior difficult to detect. The second is the political power of organized medicine and its institutional allies, which not only may be employed to obtain legislation that restricts HMO development but also helps support the prevailing ideological orientation of physicians toward personal autonomy, care of the individual patient, and technological and scientific advances. This orientation may make it difficult for HMO-associated physicians to obtain hospital staff privileges, prestigious medical school appointments and, more generally, professional and social acceptance by their peers, even in the absence of organized efforts to exclude HMO physicians from desirable resources. The third limit-causing factor is the substantial number of antitrust defenses and exemptions that seem available to place much anticompetitive behavior toward HMOs beyond the reach of antitrust law. ${ }^{8}$

7. Empirical evidence about the extent to which these restraints exist is admittedly sparse. Several explanations for this sparsity may be offered. One is the relative newness of many HMOs and of much of the relevant regulatory legislation. Another could be the relative difficulty of detecting these restraints (including unwillingness of HMOs and their physicians to report, see text accompanying notes 123-24 infra). Still another explanation, as Professor Pauly of Northwestern University suggested in commenting on a draft of this Article, is that HMOs in general have not presented a true economic threat to the fee-for-service sector, thus obviating the need for restraints. He also suggested that if restraints were widespread, there should be more "smoking guns." This latter argument may discount unduly, however, the role of professional attitudes in helping obscure anti-HMO conspiracies. See text accompanying notes 77-124 infra.

8. The primary focus of this Article is on antitrust litigation, but the factors mentioned in the text suggest that broader consideration of public law as well as private restraints on HMOs will be necessary if HMOs are to be allowed to develop fully as a competitive force within the health care industry. The basic legislative policy issues pertaining to HMOs already have been examined in depth from an "antitrust point of view." See, e.g., INSTITUTE OF MEDICINE, supra note 1; Havighurst, Regulation of Health Facilities and Services by "Certificate of Need" S9 VA. L. REv. 1143, 


\section{INITIAL CONSIDERATIONS}

\section{A. Competitive Characteristics of HMOs.}

Several characteristics of HMOs create the possibility that HMOs as a group will constitute a substantial threat to fee-for-service providers and insurers. ${ }^{9}$ First, the HMO's distinctive integration of insurance and provider functions results in an organization operating with a budget that is largely fixed in advance. This creates much stronger incentives to deliver services economically than any that exist in the fee-for-service sector, and in fact certain well-established HMOs have shown a marked ability to reduce substantially the total costs of medical care to consumers. ${ }^{10} \mathrm{HMOs}$ also may encourage more comprehensive and integrated provision of services in order to take advantage of economies of scale and of integration. ${ }^{11}$ Thus, both economic theory and empirical studies suggest that HMOs can be relatively efficient entrants into health care markets. In any event, new HMOs have tended to enter markets that are experiencing the most rapid increases in health care costs and insurance premiums. ${ }^{12}$

Second, HMOs also may take business from other providers and insurers because of certain quality improvements that could result from their unique financial and organizational structure. ${ }^{13}$ For example, attempts by HMOs to reduce surgery and drug costs should help focus attention of HMO physicians on the problem of eliminating unnecessary surgery and drug prescriptions. ${ }^{14}$ Similarly, HMO physicians, at least those who are paid on a salaried or profit-sharing basis, should have less incentive than fee-for-service physicians to refrain from referrals or consultations, since HMO physicians stand to lose less income

1204-15 (1973); Havighurst \& Bovbjerg, Professional Standards Review Organizations and Health Maintenance Organizations; Are They Compatible?, 1975 UTaн L. Rev. 381. See also Kissam \& Johnson, Federal HMO Laws, Kissam \& Johnson, State HMO Laws.

9. The following discussion is based in part on a summary of the literature about HMO performance in Kissam \& Johnson, Federal HMO Laws 1167-83.

10. See M. Roemer, Health Insurance EfFects: Services, Expenditures and AtTITUDEs 3-8, 43-49 (1972); Donabedian, supra note 3, at 16-17; Roemer \& Shonick, supra note 3, at 294-95.

11. See Auger \& Goldberg, supra note 3, at 358; Roemer \& Shonick, supra note 3, at 301.

12. See McNeil \& Schlenker, HMOs, Competition and Government, 53 MILBANK MEMorial FUND Q. 195, 200-01 (1975).

13. The quality improvements discussed here may be distinguished conceptually from other quality improvements-for example, more comprehensive services-that HMOs are able to offer because of their more efficient performance.

14. For surveys of the kinds and estimated amounts of harmful, unnecessary surgery and drug prescriptions in this country, see Brody, Incompetent Surgery Is Found Not Isolated, N.Y. Times, Jan. 27, 1976, at 1, col. 6; Rensberger, Thousands a Year Killed by Faulty Prescriptions, N.Y. Times, Jan. 28, 1976, at 1, col. 7. 
than their fee-for-service counterparts by making referrals or requesting consultations. If HMOs are able to communicate these and other quality-of-care advantages effectively to potential subscribers, ${ }^{15}$ they would possess another effective economic weapon with which they could threaten the fee-for-service sector.

Third, the HMO's basic concept or goal of considering quality/cost tradeoffs and certain methods used to implement this concept may threaten the psychological well-being and social status of fee-forservice physicians. The "commercial" attitude of HMOs toward the delivery of medical care may help "break down the myth of the priesthealer."16 In other words, the emphasis of HMOs on clinical forms of medicine, mandatory second opinions and substantial delegation of medical acts to nonphysicians could influence public attitudes about the nature of appropriate medical practice. This process not only may have economic ramifications (in terms of changing tastes and demand for medical care) but also may damage physicians' sense of personal security and their relative social position in the community. Similar kinds of losses might also occur as a result of fee-for-service physicians accepting more outside review of their work as part of their competitive response to HMOs. Because of this psychosocial element in the HMO threat, reactions to new HMOs by physician competitors may be fiercely emotional, based on deeply-held individual beliefs of a moral nature, and often disproportionate to the scale of the economic threat that an HMO portends. This situation can result in anticompetitive behavior that is difficult to detect and, if discovered, often may be beyond the reach of antitrust law. ${ }^{17}$

Significantly, the HMO form may itself be used by fee-for-service providers and insurers in a preemptive or defensive manner to deter entry by or to discipline more aggressive, independently-sponsored HMOs. ${ }^{18}$ Defensive HMOs are likely to set their premiums at entry limiting levels and to recruit aggressively only among those groups that are most likely to be attracted to competitive HMOs. Furthermore, where these HMOs are arms of large, multi-market "monopolies" such as Blue Cross or state medical societies, there may be particular incentives for them to engage in predatory pricing or promotion against an

15. Consumer ignorance or indifference and state legal restraints on HMO advertising would appear to be the major obstacles to effective communication of this sort.

16. Kessel, Commentary on the Papers, in Regulating Health Facilities Construction 35 (C. Havighurst ed. 1974).

17. See text accompanying notes 105-13 infra.

18. See Havighurst, HMOs 759-77, 789; Havighurst, Speculations on the Market's Future in Health Care, supra note 4, at 257-59. 
individual $\mathrm{HMO}$ trying to enter a single market. ${ }^{19}$

\section{B. The Historical Confrontation.}

Organized medicine's initial reaction to HMO development in the 1930s and 1940s was to condemn HMOs as a form of "unethical medical practice" and to resist their development in a relatively open and formal manner. The claim of unethical practice often included the suspect charge that HMOs provided "unreasonable competition" for physicians. ${ }^{20}$ Nonetheless, this claim does have a public interest aspect that is not entirely without intuitive appeal. HMOs' particular financial incentives arguably could produce certain kinds of over-economizing that are damaging to patients. ${ }^{21}$ Their emphasis upon clinical medicine also may disrupt the traditional relationship of trust between physician and patient that arguably is a significant factor in good quality care. ${ }^{22}$ Consumers' knowledge of medical care quality generally is

19. See R. Posner, Economic ANalysis of LAw 223-25 (2d ed. 1977). See text accompanying notes 219-22 infra. See also Areeda \& Tumer, Predatory Pricing and Related Practices Under Section 2 of the Sherman Act, 88 HARV. L. REv. 697, 698-99 (1975).

Defensive use of HMOs seems most likely to occur in one of three forms. One is the "medical care foundation" (MCF) that is being established in rather substantial numbers by county medical societies and largely in areas where other HMOs exist or threaten to develop. See R. Wetherville \& J. NordBy, A Census of HMOs: July, 1975, 10 (1975); Kissam \& Johnson, Federal HMO Laws 1178 n.103. MCFs reimburse their participating physicians on a fee-forservice basis, subject to the total prepayments collected from subscribers. Typically, they are open for participation by all physician members of a county medical society who agree to accept various controls over their practice (such as maximum fees and claims and peer review) in serving MCF subscribers. See Auger \& Goldberg, supra note 3, at 361-63. This organizational form differs dramatically from the closed-panel HMO, which typically employs physicians on a salaried or profit-sharing basis and provides its services in physically integrated group practice facilities.

A second common type of defensive HMO may be those sponsored by Blue Shield and Blue Cross plans ("the Blues") in order to protect their relatively sizeable shares of private health insurance markets. See J. Krizay \& A. Wilson, The Patient As Consumer 3 (1974). Admittedly, the Blues in some markets may be interested in using HMOs to regain customers from commercial health insurers. In other areas, however, where the Blues still enjoy substantial market power and good relations with their physician and hospital founders, the defensive motive may predominate. See Goldberg \& Greenberg, The Effect of Physician-Controlled Health Insurance, 2 J. HealTH POL., POL'Y \& L. 48 (1977).

A third defensive type of HMO could be one established by a single or dominant hospital in a relatively small city, with the purpose of serving a selected population that otherwise might enroll in a more independent HMO. See Havighurst, HMOs 766-67. This kind of HMO, which presumably would be established with the consent if not the recommendation of the hospital's medical staff, would not be as threatening to fee-for-service providers as an aggressively expanding, more independent HMO.

20. See, e.g., American Medical Ass'n v. United States, 130 F.2d 233, 238-40 n.23 (D.C. Cir. 1942), aff' 317 U.S. 519 (1943). At the time of this suit the American Medical Association's ethical standards allowed some forms of prepaid medical practice but not those that provided "unreasonable competition" for physicians. Id.

21. See Havighurst, HMOs 754-56.

22. See Klarman, Analysis of the HMO Proposal-Its Assumptions, Implications, and 
recognized to be too imperfect to allow consumers themselves to guard against potential harms of these kinds. Therefore, the argument runs, physicians who have the knowledge to protect consumers from inferior quality care also have a professional duty to guard them from injury by controlling prepaid medical practices. Although this argument may have some lingering attractiveness, ${ }^{23}$ it seems deficient in that it ignores a number of less restrictive constraints on HMOs that tend to minimize the risks of poor quality care. Among these are medical malpractice law, quality-of-care regulation by public agencies and the HMOs' need to market insurance policies, which often will be purchased in effect by employers or unions with resources to conduct their own quality-ofcare assessments. ${ }^{24}$

Fee-for-service physicians launched their attack on HMOs by employing three basic tactics: restrictive professional practices, the formation and use of physician-sponsored Blue Shield plans to deter or discipline HMOs and the restrictive use of various state laws. This tale of obstruction has been told well by others, ${ }^{25}$ but a review of its leading themes will help suggest the kinds of anticompetitive behavior that HMOs may continue to face and also will reveal some settled and unsettled questions of antitrust law.

1. Private Restraints: The Early Antitrust Cases. One early line of defense thrown up by fee-for-service physicians consisted of restrictive professional practices that seemed likely to have a devastating effect upon HMO development. Specifically, early HMOs and their physicians faced exclusion from county medical societies ${ }^{26}$ and hospital

Prospects, in University of Chicago Center for Health Administration Studies, Health Maintenance Organizations: A Reconfiguration of the Health Services SysTEM 24, 33 (1971).

23. Compare the argument for an exemption from antitrust law for all forms of professional self-regulation by lawyers in Goldfarb v. Virginia State Bar, 421 U.S. 773, 786-87 (1975), in which the Supreme Court rejected the argument for an absolute exemption but did note that "[t]he public service aspect, and other features of the professions, may require that a particular practice, which could properly be viewed as a violation of the Sherman Act, be treated differently." Id. at 788 n.17.

24. See Auger \& Goldberg, supra note 3, at 390-91; Havighurst, HMOs 755-56.

25. See, e.g., authorities cited in note 6 supra. On the use of Blue Shield plans to deter HMOs as well as other forms of "objectionable" third party health insurance, see Competition in the Health Services Market: Hearings Before the Subcomm on Antitrust and Monopoly of the Senate Comm on the Judiciary, 93d Cong., 2d Sess. 1076-77 (1974) (statement of Clark C. Havighurst); Goldberg \& Greenberg, supra note 19; Havighurst, HMOs 769-72.

26. See American Medical Ass'n v. United States, 317 U.S. 519, 529-33 (1943); Group Health Coop. v. King County Medical Soc'y, 39 Wash. 2d 586, 616, 625-27, 237 P.2d 737, 754, 758-59 (1951); cf. United States v. Oregon State Medical Soc'y, 95 F. Supp. 103, 105, 109 (D. Or. 1950), affd, 343 U.S. 326 (1952) (exclusion from county medical societies of physicians cooperating with commercial health insurers). The consequences to a physician of exclusion from a county medi- 
medical staffs, ${ }^{27}$ the refusal of fee-for-service physicians to consult with or accept referrals from HMO physicians, ${ }^{28}$ and the dissemination of negative (and allegedly false) propaganda to the general public and physicians about the nature of HMO operations. ${ }^{29}$ These practices were planned and conducted by organized groups of physicians, in particular state and county medical societies. A series of early cases considered the antitrust implications of these overt attempts to destroy developing HMOs. While the holdings and analyses of these cases have been discussed elsewhere, ${ }^{30}$ it should be noted here that these early cases clearly held that professional self-regulation measures taken against HMOs and their physicians because of the HMO organizational form are the kinds of restraints considered illegal under antitrust law. ${ }^{31}$ The courts suggested also that any more specific professional self-regulation measures against HMOs would be examined most carefully. ${ }^{32}$ The early cases did not, however, determine whether restraints against HMOs have a substantial effect upon interstate commerce, a

cal society may include denial of admitting privileges at local hospitals, failure to obtain specialty ratings or continuing education, and higher malpractice rates. Group Health Coop. v. King County Medical Soc'y., 39 Wash. 2d at 626, 631-32, 237 P.2d at 759, 761-62; Kessel, supra note 6, at 30-32; Rayack, supra note 6, at 666-67.

27. See American Medical Ass'n v. United States, 317 U.S. 519, 529-33 (1943); Group Health Coop. v. King County Medical Soc'y, 39 Wash. 2d 586, 616-25, 237 P.2d 737, 754-58 (1951). This practice of course would be most damaging to HMOs that do not control their own hospital facilities, but it also might limit the operational flexibility and comprehensive nature of services offered by smaller hospital-based HMOs. See id. at 624-25, 237 P.2d at 758.

28. See American Medical Ass'n v. United States, 317 U.S. 519, 529-33 (1943); Group Health Coop. v. King County Medical Soc'y, 39 Wash. 2d 586, 627-29, 237 P.2d 737, 759-60 (1951).

29. See Group Health Coop. v. King County Medical Soc'y, 39 Wash. 2d 586, 630, 237 P.2d 737, 761 (1951); Rayack, supra note 6, at 680.

30. See Goldberg \& Greenberg, supra note 19, at 59-62; Havighurst, HMOs 777-81.

31. See American Medical Ass'n v. United States, 317 U.S. 519 (1943). The Court held in this case that a restraint of trade could be proved by evidence that fee-for-service physicians and their medical societies had conspired to exclude HMO physicians from local societies and hospitals and to refrain from referrals and consultations with HMO physicians. On its face, this case seems to reject the professional self-regulation defense for anticompetitive behavior that is designed to affect HMOs. See Havighurst, HMOs 777-78. In view of the Supreme Court's cryptic footnote 17 in Goldfarb v. Virginia State Bar, 421 U.S. 773, 788 n.17, however, which provided that some professional restraints may receive special treatment under the Sherman Act, the possibility of a professional self-regulation defense may remain in some HMO cases. See text accompanying notes 75-76 infra.

32. See Group Health Coop. v. King County Medical Soc'y, 39 Wash. 2d 586, 237 P.2d 737 (1951). The Washington Supreme Court held in this case that a plaintiff HMO had proved the existence of three restrictive practices: concerted exclusion of HMO physicians from the county society, concerted exclusion of these physicians from hospitals and concerted refusals of fee-forservice physicians to consult with these physicians. Id. at 616-32, 237 P.2d at 754-62. The court noted the absence of any evidence to support the defendants' claim of substandard service by HMO physicians, and the failure of the medical society to base its claim on an examination of the HMO's operations. Id. at 605-14, 237 P.2d at 748-54. 
finding which is necessary before the Sherman Act can apply. ${ }^{33}$ Nor do they provide useful precedent for attacking anticompetitive behavior against HMOs by fee-for-service controlled health insurers; ${ }^{34}$ in fact the trial court decision in one of the cases suggests that substantial leeway might be provided in this regard. ${ }^{35}$

By the early 1970s observers of the HMO scene could report that medical societies were taking a more liberal attitude toward the HMO, perhaps in significant part because of the above noted-decisions and several subsequent out-of-court settlements. ${ }^{36}$ Nonetheless, these reports tended to come from relatively well-established HMOs, and concern still was expressed about "more subtle techniques" of organized medicine that might obstruct HMO development and about professional resistance to HMO expansion into new communities. ${ }^{37}$ These contemporary concerns will be examined after the early public law restraints against HMOs are first surveyed.

2. Public Restraints: Restrictive Use of State Laws. Fee-for-service physicians also moved against HMOs by obtaining or attempting to enforce a variety of state laws that were designed for other purposes but could be used to prohibit or retard HMO operations. One quite basic approach was to use state licensing boards to revoke or deny licenses to HMO physicians. The practice of "unethical medicine" and more technical claims relating to "unethical" or "illegal" physician advertising and physician delegation of medical acts were reasons given to support these actions. ${ }^{38}$ The effectiveness of this approach was reduced, however, by some healthy political opposition and judicial review of

33. The Supreme Court, in American Medical Ass'n v. United States, 317 U.S. 519 (1943), found no reason to discuss this question, because the case involved an HMO in the District of Columbia, for which the Court had jurisdiction under section 3 of the Sherman Act, 15 U.S.C. \& 3 (1976). Only state antitrust law was involved in the other major HMO case, Group Health Coop. v. King County Medical Soc'y, 39 Wash. 2d 586, 237 P.2d 737 (1951). In a third antitrust case, which involved physician restraints against commercial health insurance companies, neither the trial court nor the Supreme Court dealt conclusively with the interstate commerce issue as it applies to health services and insurance. See United States v. Oregon State Medical Soc'y, 343 U.S. $326,331,338-39$ (1952).

34. Cf. United States v. Oregon State Medical Soc'y, 343 U.S. 326 (1952) (the United States unsuccessfully urged that fee-for-service physicians, their medical societies and their Blue Cross plans had violated the Sherman Act by conspiring to restrain and monopolize the sale of medical insurance in the state).

35. See United States v. Oregon State Medical Soc'y, 95 F. Supp. 103, 116-19 (D. Or. 1950), affd, 343 U.S. 326 (1952).

36. See Note, supra note 2 , at $958-59$.

37. Id. 959-60.

38. See Kessel, supra note 6, at 34-36. See also Garfield v. Board of Medical Examiners, 99 Cal. App. 2d 219, 221 P.2d 705 (1950). 
the administrative process. ${ }^{39}$ It remains true, though, that the administrative licensing process might be used unfairly against HMOs by feefor-service physicians in varying ways. State medical licensing boards continue to be dominated by organized medicine, ${ }^{40}$ and these boards may be able to restrain HMO operations or sanction their physicians unfairly under state legal restrictions against physician advertising or innovative delegation of medical acts. ${ }^{41}$

The success of organized medicine in obtaining Blue Shield enabling laws established another restraint on HMO operation. These statutes had the effect of limiting or prohibiting operation of any medical service plan, including that of an HMO, that was not controlled by fee-for-service physicians. ${ }^{42}$ Typically these statutes require any nonprofit medical service plan to obtain county medical society approval, to include a certain percentage of local physicians as members or to be open to all physicians who desire to join. ${ }^{43}$ Some early HMOs were able to avoid the apparently prohibitory effect of these provisions by judicial interpretation of the legislative intent behind Blue Shield laws, ${ }^{44}$ by obtaining flexible interpretations of the laws by administrative officials, ${ }^{45}$ or through successful constitutional attack based on due process and unlawful delegation of authority theories. ${ }^{46}$ The Health Maintenance Organization Act of $1973^{47}$ preempts state Blue Shield

39. See W. MACCOLL, supra note 2, at 21; Kessel, supra note 6, at 35-36.

40. These boards are composed almost entirely of physicians appointed on the recommendation or nomination of state medical societies. Forgotson, Roemer \& Newman, Legal Regulation of Health Personnel in the United States, in 2 REPORT OF THE NATIONAL ADVISORY COMM'N ON Health MANPOWER 279, 296-97 (1967). There have been recent moves to include "public members" on medical licensing boards, but physicians still retain overwhelming voting power where this has occurred. See Health Resources Administration, U.S. Dep'T of Health, EducaTion, and Welfare, State Regulation of Health MaNpower 157-60 (1977).

41. On state legal standards that seem to unduly restrict advertising by HMOs, see Kissam \& Johnson, State HMO Laws 44. On the complex nature of state legal restrictions against the innovative delegation of medical acts by physicians, see Kissam, Physician's Assistant and Nurse Practitioner Laws: A Study of Healh Law Reform, 24 KAN. L. REv. 1 (1975). Cf. Feminist Women's Health Center, Inc. v. Mohammad, 415 F. Supp. 1258 (N.D. Fla. 1976), rev'd on other grounds on rehearing, No. TCA 75-186 (N.D. Fla. Nov. 18 \& Dec. 3, 1976) (now on appeal to the Fifth Circuit Court of Appeals) (informal sanctions from a state medical board against physicians working in a low-cost abortion clinic).

42. See, e.g., Hansen, Laws Affecting Group Health Plans, 35 IowA L. REv. 209, 223-28 (1950); Note, supra note 2, at 962-69.

43. Note, supra note 2, at 963.

44. See Complete Service Bureau v. San Diego County Medical Soc'y, 43 Cal. 2d 201, 272 P.2d 497 (1954).

45. See Note, supra note 2, at 964-67.

46. See Group Health Ins. v. Howell, 43 N.J. 104, 202 A.2d 689 (1964); Group Health Ins. v. Howell, 40 N.J. 436, 193 A.2d 103 (1963).

47. 42 U.S.C. $\$ 300 \mathrm{e}$ (Supp. V 1975). The preemption provision mentioned in the text is section $300 \mathrm{e}-10(\mathrm{a})(\mathrm{I})(\mathrm{A})-(\mathrm{C})$. In this decade three pieces of federal legislation have been enacted 
laws for qualifying HMOs. Moreover, HMO enabling statutes recently enacted by more than half of the states ${ }^{48}$ have helped to protect

to promote HMO development by improving their access to public and private health insurance markets, preempting certain forms of restrictive state laws, and providing developmental subsidies. In 1972 the Medicare and Medicaid laws were amended to authorize prepaid contracts between these programs and HMOs serving their beneficiaries. Social Security Amendments of 1972, Pub. L. No. 92-603, $\S \S 213$ (a), 226(a), 86 Stat. 1329, 1384, 1396 (codified at 42 U.S.C. $\$ \S$ 1395mm, 1396(c)(23) (Supp. V 1975)). The Health Maintenance Organization Act of 1973 followed, and then in 1976 the previous laws were amended in several significant respects. Health Maintenance Organization Amendments of 1976, Pub. L. No. 94-460, 90 Stat. 1945 (codified at scattered sections of 42 U.S.C.A. (West Supp. 1977)).

The general problem with this legislation, from an antitrust point of view, is that it fails to promote HMOs as a fully competitive force in health service markets. See INSTITUTE of MEDICINE, supra note 1. To be sure, the 1976 amendments in general reduced the costs to HMOs of participating in federal programs, but because of competing policy goals and continuing political opposition to HMOs these amendments did not remove all anticompetitive burdens on federally qualified HMOs. See Kissam \& Johnson, Federal HMO Laws 1199-1222; BusINEsS WeEK, May 30, 1977, at 74-76. Remaining statutory obstacles include requirements under the Health Maintenance Organization Act that qualified HMOs offer relatively comprehensive insurance benefits to their subscribers, 42 U.S.C. $\$ 300 \mathrm{e}-1$ (1) (Supp. V 1975), use community rather than experience rating to establish premium levels, id. $\S 300 \mathrm{e}(\mathrm{b})(1)(\mathrm{c})$, and assume most of the financial risk involved under their policies, id. $\S 300 \mathrm{e}(\mathrm{c})(2)$. The assumption of financial risk requirements allow qualified HMOs to reinsure only against risks of catastrophic illnesses, extraordinary aggregate losses, and services provided to HMO enrollees by other persons or institutions. Id. This provision effectively eliminates the possibility of qualified HMOs reinsuring against major risks like hospital costs.

It also remains true that only relatively large HMOs may qualify for risk-sharing prepaid contracts with the Medicare program. Id. $\S 1395 \mathrm{~mm}(\mathrm{i})(2)(\mathrm{A})$. See Kissam \& Johnson, Federal HMO Laws 1227-28 n.430. Moreover, various Medicare and state Medicaid requirements on prepaid contracts with HMOs have been designed to obtain immediate government cost savings but appear to unduly increase the profitability of such contracts for HMOs. See Kissam \& Johnson, State HMO Laws 59-62. Finally, the 1976 amendments introduced a new requirement that Medicare and Medicaid HMOs must comply with various standards under the Health Maintenance Organization Act, 42 U.S.C.A. $\$ \S 1395 \mathrm{~mm}(\mathrm{~b})(1)(B), 1396(\mathrm{~m})(1)(\mathrm{A})(\mathrm{ii})$ (West Supp. 1977), a requirement just implemented for Medicare and Medicaid HMOs by regulations published in 43 Fed. Reg. 5822 (1978) (to be codified at 42 C.F.R. $\$ \S 405.2001,405.2050(b), 499.82)$. The amendments also included the potentially costly requirements that one-third of the HMO's governing body be members with no ownership or financial interests, 43 Fed. Reg. 5824 (1978), and that the HMO furnish health education and medical social services to all members whether or not these services are funded by Medicare or Medicaid. Id. 5825.

48. As of July, 1976, HEW listed 27 states with HMO enabling laws and noted that such legislation was pending in about 10 other states. Health Services Administration, U.S. Dep'T OF Health, Education and Welfare, Health Maintenance Organizations: 2d ANNUAL REPORT TO CONGRESS 6 (1976). These laws are designed to free HMOs from the earlier public law restraints and to provide financial and quality-of-care regulation that is tailored to meet the unique characteristics of HMOs. See Kissam \& Johnson, State HMO Laws 35-36. These laws in general avoid many of the unnecessarily costly requirements imposed by the federal Health Maintenance Organization Act. See note 47, supra. For example, state HMO statutes require neither very sweeping comprehensive benefits nor community rating for premiums. See Kissam \& Johnson, State HMO Laws 47-48, 50-51. Most of these acts allow HMOs to contract for substantial reinsurance of risks. See id. 52.

On the other hand, state HMO enabling statutes do introduce some new potentially anticompetitive obstacles, and they tend to follow the federal act in its failure to free HMOs from overly 
HMOs. Nonetheless, non-federally qualified HMOs located in states with Blue Shield laws but no HMO statutes still may face extra development costs for protracted litigation or political lobbying in order to organize under the avoidance techniques just noted. ${ }^{49}$

A third attempt to eliminate HMOs consisted of legal actions based on the claim that HMOs were violating the time-honored common law rule against the corporate practice of medicine. ${ }^{50}$ This charge was met successfully in several cases by arguments that the HMO in question was a non profit one and so organized as to allow its physicians to practice medicine without lay interference. ${ }^{51}$ This problem, too, has been diminished by the new federal and state HMO laws, which explicitly or implicitly preclude application of the corporate practice rule to many HMOs. ${ }^{52}$ Yet non-federally qualified HMOs in states without HMO enabling statutes may remain vulnerable, especially if they are profit-seeking organizations. ${ }^{53}$

Early HMOs also were often subjected to inappropriate financial regulation under general insurance codes or Blue Shield statutes. ${ }^{54} \mathrm{Al}-$

restrictive state restrictions on advertising and expanded medical delegation. In particular, most statutes authorize insurance departments to regulate HMO premiums, which generally seems inappropriate in view of HMOs' incentives to contain costs and compete for business against established insurers. See id. 52-54. A few laws also apply only to nonprofit HMOs, see MinN. STAT. ANN. § 62D.02(4) (West Cum. Supp. 1977); PA. StaT. AnN. tit. 40, § 1554(a) (Purdon Supp. 1977); S.D. COMPILED LAwS ANN. \& 58-41-2 (Supp. 1977), and under at least one state regulation HMOs are subject to quality assurance review by the regional PSRO, see Iowa Ins. Dep't Rule 12.5(11)(b) (1974). Several states follow the Health Maintenance Organization Act in expressly prohibiting HMO advertising from addressing quality of care matters, and no state's HMO law expressly authorizes such advertising. See Kissam \& Johnson, State HMO Laws 44 . Nor do these statutes attempt to free qualified HMOs from restrictions in other state laws on expanded medical delegation. Id. 55.

49. See Note, supra note 2, at 967-68.

50. See id. 960-62. For discussion of this rule and the inappropriateness of applying it to HMOs, see Hansen, supra note 42, at 211-19; Kissam \& Johnson, State HMO Laws 30 n.66.

51. See Group Health Ass'n v. Moor, 24 F. Supp. 445, 446 (D.D.C. 1938), affd on other grounds sub nom. Jordan v. Group Health Ass'n, 107 F.2d 239 (D.C. Cir. 1939); Complete Service Bureau v. San Diego County Medical Soc'y, 43 Cal. 2d 222, 228, 272 P.2d 497, 502 (1954); Group Health Coop. v. King County Medical Soc'y, 39 Wash. 2d 586, 661-62, 237 P.2d 737, 777-78 (1951).

52. See Kissam \& Johnson, State HMO Laws 29-30, 39.

53. In at least one state some not-for-profit HMOs as well as profit-making ones are vulnerable. In 1971 Texas codified its corporate practice rule to allow only physician-controlled nonprofit corporations to engage in the delivery of medical care. TEX. CODE ANN. tit. 71, § 4509a (Vernon 1972). This provision was upheld as a reasonable regulation of medical care against constitutional claims of a consumer-controlled nonprofit organization that attempted to organize and incorporate an HMO under Texas law and was rejected by the state. Garcia v. Texas State Bd. of Medical Examiners, 384 F. Supp. 434 (W.D. Tex. 1974), affd mem., 421 U.S. 995 (1975).

54. See Note, supra note 2, at 969-74. In at least one case, however, an HMO was able to avoid such regulation by a judicial decision that its operations did not fall within the scope of the insurance law. Group Health Ass'n v. Moor, 24 F. Supp. 445 (D.D.C. 1938), affd sub nom. Jordan v. Group Health Ass'n, 107 F.2d 239 (D.C. Cir. 1939). 
though HMOs are insurers, their distinctive characteristic of providing services rather than cash upon occurrence of the insurable event means that initial capitalization and reserve requirements appropriate for other insurers may be overly restrictive for HMOs. ${ }^{55}$ This problem, too, has been mitigated by the Health Maintenance Organization Act, which preempts application of general state insurance capitalization and reserve requirements to federally qualified $\mathrm{HMOs,},{ }^{56}$ and by state statutes that provide for unique financial controls over HMOs. ${ }^{57}$ Even under state HMO laws, however, inappropriate financial regulation may persist. State insurance departments remain generally responsible for financial regulation of HMOs, and these departments may be captives of the fee-for-service health insurers or of their past regulatory experience with cash payment insurance. ${ }^{58}$ There also is some evidence that new HMO formation has been deterred by apparently high financial requirements established by or under state HMO statutes. ${ }^{59}$

In summary, the Health Maintenance Organization Act of 1973 and the new state HMO enabling statutes have changed substantially the legal environment within which many HMOs operate. This legislation has not removed all public law anticompetitive restraints on HMOs, however, and, as will be shown, such restraints may play an important role in future antitrust litigation designed to protect HMOs. ${ }^{60}$

\section{Private Anticompetitive ObStacles}

The relevant cases, statutes and literature suggest a considerable variety of means, many of them new, that the fee-for-service sector may employ unfairly to block HMO development. This section will consider the application of federal antitrust law to anticompetitive behavior by private entities, although some of these "private" restraints can take on a "public" character.

\section{A. The Interstate Commerce Question.}

The early antitrust cases involving anti-HMO restraints did not resolve the issue of whether restraints on HMOs ever may be defended on the ground that they are outside the scope of interstate commerce to

55. See InStrTute of Medicine, supra note 1, at 23-24; Note, supra note 2, at 972-73. But cf. INSTITUTE OF MEDICINE, supra note 1, at 68 (a dissenting opinion claiming that the efficiency of any regulatory alternative to reserve requirements is not clear and deserves further study).

56. 42 U.S.C. $\& 300 \mathrm{e}-10(\mathrm{a})(1)(\mathrm{D})$ (Supp. V 1975).

57. See Kissam \& Johnson, State HMO Laws 41-42.

58. Id. 38.

59. See McNeil \& Schlenker, supra note 12 , at 207-08.

60. See text accompanying notes 114-18, 150-69 \& 296-315 infra. 
which sections 1 and 2 of the Sherman Act apply ${ }^{61}$ Two arguments are available to establish the "substantial effect" on interstate commerce of any anti-HMO restraint. ${ }^{62}$ The first, which focuses on the HMO's purchase of supplies and other inputs from interstate commerce, draws strong support from the Supreme Court's recent decision in Hospital Building Co. v. Rex Hospital. ${ }^{63}$ This approach alone, however, might require a difficult determination with respect to smaller HMOs. The second argument focuses on the HMO as insurer and its impact on the interstate transactions of other health insurers. This approach is more speculative, but it is logically more satisfying and seems to avoid the difficulty arising from a determination in the case of smaller HMOs.

In Rex Hospital the Supreme Court was faced with the issue of whether locally-instituted restraints against a hospital's expansion from a 49 bed facility to one of 140 beds could be covered by the Sherman Act. Plaintiff's complaint had been dismissed because of an insufficient nexus between the alleged antitrust violations and interstate commerce. Plaintiff hospital had alleged a cluster of contacts between its operations and interstate commerce, such as purchase of up to fifty percent of the hospital's drugs and other supplies from out-of-state sellers, significant revenues from out-of-state insurance companies and from the federal government through Medicare and Medicaid, a substantial number of out-of-state patients, a management service fee paid to the hospital's out-of-state parent, and out-of-state financing for the hospital's planned expansion. ${ }^{64}$ The Court held that this "combination of factors," if proved in subsequent proceedings, was "certainly sufficient to establish a 'substantial effect' on interstate commerce." 65

The Court also held that the "indirect" nature of the alleged effect on interstate commerce and the absence of any activity "purposely directed toward interstate commerce" were immaterial to the resolution

61. Both sections apply only to "trade or commerce among the several States, or with foreign nations." 15 U.S.C. $\$ \S 1,2$ (1976). The Clayton and Robinson-Patman Acts, id. \$§ 12-27, apply only to "commodity" transactions or to persons "engaged in [interstate] commerce" and therefore are not directly relevant to antitrust protection of HMOs.

62. For recent discussions of the "flow of commerce" and "substantial effect" tests for resolving interstate commerce questions under the Sherman Act, see L. SullivaN \& 233a; Furgeson, The Commerce Test for Jurisdiction Under the Sherman Act, 12 Houston L. REv. 1052 (1975); Comment, The Confusing World of Interstate Commerce and Jurisdiction Under the Sherman Act-A Look at the Development and Future of Currently Employed Jurisdictional Tests, 21 VILL. L. REV. 721 (1976). HMOs do not seem to operate within the flow of commerce in most instances because their insurance and provider services are usually sold to policyholders residing within one state.

63. 425 U.S. 738 (1976).

64. Id. at 741.

65. ' Id. at 744 . 
of the interstate commerce question. ${ }^{66}$ In so doing the Court in effect overruled the approach of lower courts in several circuits that had required "direct" or "purposeful" effects of alleged restraints on interstate commerce in order to find Sherman Act jurisdiction. ${ }^{67}$

Rex Hospital clears the way for applying the Sherman Act to antiHMO restraints on the ground that the restraints will affect adversely an HMO's purchase of supplies in interstate commerce and the HMO's provision of service to Medicare and Medicaid beneficiaries. But the Court's reliance on the entire cluster of alleged interstate contacts leaves open the ultimate question of where the line between substantial and de minimus contacts will or should be drawn. Many HMOs may purchase a significant percentage of their supplies from interstate commerce (in particular, drugs) or otherwise affect such commerce (for example, by drug prescriptions), ${ }^{68}$ but for smaller HMOs the dollar amount of commerce so affected may not be large. Moreover, by no means do all HMOs serve Medicare and Medicaid beneficiaries, ${ }^{69}$ and relatively few HMOs may have the other interstate contacts possessed by the plaintiff in Rex Hospital.

Differences in the quantum of such interstate contacts between any HMO and the plaintiff in Rex Hospital may be easily surmountable. There would seem to be no principled distinction between the mere purchase of supplies in interstate commerce by a small HMO and the cluster of interstate contacts considered sufficient in Rex Hospital. Furthermore, circuit courts that have applied the "purchase of inputs" approach in cases involving health care institutions have not drawn any clear line between substantial and de minimus effects on interstate commerce. ${ }^{70}$

At times, however, antitrust courts have been concerned about establishing some express limits that exclude de minimus effects. ${ }^{71}$ More-

66. Id. at 744-45.

67. See Lieberthal v. North Country Lanes, Inc., 332 F.2d 269 (2d Cir. 1964); Elizabeth Hosp., Inc. v. Richardson, 269 F.2d 167 (8th Cir.), cert. denied, 381 U.S. 884 (1959); Spears Free Clinic \& Hosp. v. Cleere, 197 F.2d 125 (10th Cir. 1952). See also Furgeson, supra note 62, at 1060-65.

68. See Havighurst, HMOs 778-80.

69. See Havighurst \& Bovbjerg, supra note 8, at 383 n.9. See also Kissam \& Johnson, Federal HMO Laws 1224-30.

70. See Ballard v. Blue Shield, 543 F.2d 1075 (4th Cir. 1976) (decided after Rex Hospital); St. Bernard Gen. Hosp. v. Hospital Serv. Ass'n, 510 F.2d 1121 (5th Cir. 1975); Doctor's, Inc. v. Blue Cross, 490 F.2d 48 (3d Cir. 1973). See also Furgeson, supra note 62, at 1065-67.

71. See, e.g., Doctor's, Inc. v. Blue Cross, 490 F.2d 48, 53-54 (3d Cir. 1973). Judicial unwillingness to give the Sherman Act as broad a scope as the commerce clause seems appropriate in view of congressional silence on the intended reach of the Sherman Act and the constraining constitutional principle of federalism. Although the Supreme Court has stated that "Congress wanted to go to the utmost extent of its Constitutional power" in applying the Sherman Act to 
over, in applying the Rex Hospital approach to health care institutions some circuits have focused on more than the purchase of supplies by one institution to find Sherman Act jurisdiction. In Doctors, Inc. $v$. Blue Cross, ${ }^{72}$ for example, the Third Circuit was satisfied by plaintiff's allegations of a possibly adverse effect upon out-of-state supplies purchased by both plaintiff and other hospitals in the area whose operations might be curtailed by the alleged restraints. The court apparently emphasized the dollar amount of plaintiff's purchases in interstate commerce (\$233,000 in 1972) and the fact that defendants possessed enough market power to shut down the plaintiff and other hospitals by means of the alleged restraints. ${ }^{73}$

Should Rex Hospital's "purchase of inputs" approach to Sherman Act jurisdiction prove insufficient by itself to cover smaller HMOs faced with restraints by less powerful defendants, one may also argue that the competitive presence of the HMO is likely to have a significant effect on the interstate transactions of other insurers. ${ }^{74}$ The de minimus objection to Sherman Act jurisdiction can be answered by the qualitative argument that the efficient HMO entrant, no matter how small, could have a significant impact on the price of health insurance sold in interstate commerce.

anticompetitive behavior, United States v. Southeastern Underwriters Ass'n, 322 U.S. 533, 558 (1944), it should be noted that this oft quoted statement was made in connection with the Court's decision that insurance services constituted "commerce" under the Sherman Act and not in connection with how far the Act should extend to localized activities that in 1890 certainly were not considered to be within the commerce power. On the value of considering constraining constitutional principles such as the federalism principle in "hard cases" of statutory interpretation, see Dworkin, Hard Cases, 88 HARv. L. Rev. 1057, 1085-87 (1975).

72. 490 F.2d 48 (3d Cir. 1973).

73. Another circuit court which used a similar analysis was the Fifth Circuit, which in St. Bernard Gen. Hosp., Inc. v. Hospital Serv. Ass'n, 510 F.2d 1121 (5th Cir. 1975), followed Doctor's, Inc. in all significant respects. Finally, in Ballard v. Blue Shield, 543 F.2d 1075 (4th Cir. 1976), the Fourth Circuit applied Rex Hospital to hold that chiropractors might establish Sherman Act jurisdiction in contesting their exclusion from Blue Shield on the basis of possibly adverse effects upon out-of-state purchases, out-of-state patients and interstate health insurance companies that do pay chiropractors' claims. This holding also seemed to rely on the defendant's apparent power to injure chiropractors throughout the state. See also City of Fairfax v. Fairfax Hosp. Ass'n, 562 F.2d 280 (4th Cir. 1977).

74. These transactions include those of commercial health insurers doing business in states as foreign companies as well as those of modern Blue Shield and Blue Cross plans. Blue plans are locally based, but these plans are members of national organizations that perform significant commercial services for the local plans such as soliciting and maintaining national accounts from multi-state companies and unions. See S. LAW, BLUE Cross: What WeNT Wrono? 20-21 (2d ed. 1976). 


\section{B. Professional Restrictions.}

Fee-for-service physicians generally control the access of HMOs and their physicians to a number of essential or desirable resources. These resources include membership in county medical societies, hospital staff privileges and favorable hospital by-laws, medical school appointments and access to the referral and consulting network which exists among fee-for-service physicians. ${ }^{75}$

The prominent social position of physicians, particularly in smaller communities, also may give them the power of social disapproval that can discourage HMO participation by both physicians and consumers. $^{76}$ Fee-for-service physicians also are in a strong position to seek state legislative or administrative action that can restrain effective HMO competition. Each of these control mechanisms may be exercised in ways that raise difficult questions of antitrust law.

1. Boycotts and Refusals to Deal. Apart from collective attempts by physicians to obtain state action that disfavors HMOs, any agreement by physicians to exclude other physicians from desirable resources because of their HMO association is clearly a per se violation of section 1 of the Sherman Act. The case of American Medical Association v. United States ${ }^{77}$ and the line of more recent Supreme Court cases that apply a per se rule to group boycotts against competitors qua competitors $^{78}$ are ample authority for this proposition. This result should not be changed by the reference in Goldfarb v. Virginia State $B a r^{79}$ to the possibility that some professional restraints may justify special antitrust treatment. ${ }^{80}$ Explicit or "classic" boycotts of this sort produce substantial competitive harm, and other less restrictive meth-

75. Another important resource to HMO physicians is certification by the national specialty boards established and controlled by organized medicine. See generally R. STEVENS, AMERICAN Medicine AND THe Public InTEREst $75-414$ (1971). Decision making by these boards historically exhibited the same subjective quality and concern with an applicant physician's "ethical fitness" that has been a problem for HMO physicians trying to obtain admission to a county medical society or hospital. Id. 248-50, 319-24. Today, however, most specialty boards are employing objective tests for certification, $i d$. 343-44, and they tend to be dominated by national leaders of organized medicine and elite specialists, see, e.g., id. 327-30, who probably have little to fear from HMO practices. One thus may expect modern professional opposition to HMOs to occur mostly at a local level. See Havighurst, HMOs 767; Rayack, supra note 6, at 665 .

76. See Rayack, supra note 6, at 666; Comment, The American Medical Association: Power, Purpose and Politics in Organized Medicine, 63 YALE L.J. 937, 1019-21 (1954).

77. 317 U.S. 519 (1943).

78. See United States v. General Motors Corp., 384 U.S. 127 (1966); Silver v. New York Stock Exch., 373 U.S. 341 (1963); Klor's, Inc. v. Broadway-Hale Stores, Inc., 359 U.S. 208 (1959). See also L. Sullivan $\$ 84$.

79. 421 U.S. 773 (1975).

80. Id. at $788 \mathrm{n} .17$. 
ods of regulating HMOs' quality of care are available. ${ }^{81}$

A different situation exists with other forms of collective action by physicians that have the same anticompetitive purposes and effects as the classic boycott but can be justified by more persuasive reasons than the sweeping claim of "professional self-regulation." In these situations, Professor Sullivan notes, courts should and in effect do ask two questions. First, should the conduct be characterized, upon preliminary examination, as a group boycott that is per se illegal because it has the same purposes or effects as those of an explicit boycott? ${ }^{82}$ Second, if not, does the challenged conduct withstand a rule of reason analysis that attempts to balance competitive harms against competing legitimate values? ${ }^{83}$ Although courts in health care cases may be distracted from this two-step approach by Goldfarb's reference to special treatment of professional restraints, it will be argued below that this twostep approach remains appropriate and in effect has been followed in at least one post-Goldfarb decision involving health care. ${ }^{84}$ First, however, this two-step approach will be illustrated by a hypothetical situation. This suggests the value of Professor Sullivan's two-step approach for analyzing conduct that tends to have a boycott effect upon HMOs. It also suggests that courts may face substantial difficulty in addressing quality-of-care claims that are used by fee-for-service physicians to justify exclusion of HMOs from desirable resources.

Suppose that a non-hospital based HMO develops a new obstetrics program for normal, low-risk pregnancies. These cases are to be managed by nurse practitioners with supervision from HMO physicians on an on-call basis, and will result in patient stays of 24 hours or less in the local hospital. The HMO plans to provide these services to its own subscribers and to fee-for-service patients as well. Fee-for-service obstetricians at the hospital do not employ nurse practitioners and follow procedures that result in a four day average length of stay for normal deliveries. These physicians obtain a hospital by-law that bans giving primary responsibility to nurse practitioners and requires other procedures that will lengthen the average stay of HMO maternity patients to three days. The fee-for-service physicians justify this by-law on the ground that it reduces risk in normal deliveries by some amount,

81. See L. Sullivan \& 85; Comment, The Medical Profession and the Sherman Act: Wolf v. Jane Phillips Episcopal-Memorial Medical Center, 1976 UTAH L. Rev. 196, 208-09. Less restrictive alternatives to regulate HMOs' quality of care are described in text accompanying note 24 supra.

82. L. SULlivan $\S 86$.

83. Id. §88.

84. Veizaga v. National Bd. for Respiratory Therapy, [1977-1] TRADE CASES (CCH) ף 61,274 (N.D. Ill. Jan. 27, 1977). 
notwithstanding its substantial cost-enhancing properties. Suppose further that each side can rely on studies, all inconclusive, that suggest some increase or no increase in risk from the HMO's program. Should this kind of restraint on HMOs be considered a per se illegal boycott or, alternatively, illegal under the rule of reason?

Arguably this restraint should be characterized as a group boycott and subjected to the per se rule. The purposes of the fee-for-service physicians may be shown by their economic incentive to prevent the HMO practice ${ }^{85}$ and their use of "non objective" standards to support the by-law. ${ }^{86}$ Furthermore, one can point to several less restrictive alternatives that would ensure adequate quality of care in this situation. For example, the physician-nurse practitioner relationship is subject to explicit regulation by many states, often in quite detailed terms, ${ }^{87}$ and in any event physician and nurse practices are regulated generally by state licensing boards. Similarly, the hospital and HMO are subject to quality-of-care regulation by a variety of governmental and external private bodies. ${ }^{88}$ Finally, this kind of quality-of-care issue may better be left to a case-by-case determination under medical malpractice law. ${ }^{89}$ Malpractice cases provide the chance to focus expert evidence upon particular harms that have occurred rather than speculative harms that are likely to be alleged in antitrust cases to justify professional self-regulation. ${ }^{90}$

The hospital and fee-for-service physicians will defend their action as necessary to provide more-than-minimum quality to the hospital's patients. This is an apparently legitimate competing value, and one which may draw particular support from recent malpractice decisions making hospitals and even entire medical staffs jointly liable for incompetent practices within the hospital. ${ }^{91}$ If antitrust courts are un-

85. See Feminist Women's Health Center, Inc. v. Mohammad, 415 F. Supp. 1258, 1269 (N.D. Fla. 1976), rev'd on other grounds on rehearing, No. TCA 75-186 (N.D. Fla. Nov. 18 \& Dec. 3, 1976) (now on appeal to the Fifth Circuit Court of Appeals).

86. See 415 F. Supp. at 1270. See also Radiant Burners, Inc. v. Peoples Gas Light \& Coke Co., 364 U.S. 656 (1961); United States v. Johns-Manville Corp., 259 F. Supp. 440 (E.D. Pa. 1966).

87. See Kissam, Physician's Assistant and Nurse Practitioner Laws: A Study of Health Law Reform, 24 U. KAN. L. REv. 1 (1975).

88. See Kissam \& Johnson, State HMO Laws 45-47; Worthington \& Silver, Regulation of Quality of Care in Hospitals: The Need for Change, 35 LAw \& CoNTEMP. Prob. 305 (1970).

89. For a good discussion of medical malpractice law and HMOs, see Bovbjerg, The Medical Malpractice Standard of Care: HMOs and Customary Practice, 1975 DukE L.J. 1375. On the quality of care restraints imposed on early HMOs by malpractice law, see Curran \& Mosely, The Malpractice Experience of Health Maintenance Organizations, 70 Nw. U.L. Rev. 69 (1975).

90. See, e.g., Group Health Coop. v. King County Medical Soc'y, 39 Wash. 2d 586, 607-15, 237 P.2d 737, 749-53 (1951). If previous harms have occurred, the question may be asked why fee-for-service physicians have not referred these cases to other authorities.

91. See Darling v. Charleston Community Memorial Hosp., 33 Ill. 2d 326, 211 N.E.2d 253 
willing to question the relative subjectivity of the standards used to uphold this kind of by-law, ${ }^{92}$ they may well choose to apply a rule of reason analysis. This would involve balancing quite disparate effects (competitive harm versus medical quality) and would place the burden on the plaintiff to show that the competitive harms outweigh the benefits. Applying the rule of reason would also encourage courts to defer to the opinion of the professional majority about the need for higher quality care. ${ }^{93}$ In this thicket HMOs may have difficulty establishing their case.

The suggested approach for analyzing physician boycotts and other boycott-like behavior against HMOs may be related to the general issue of how post-Goldfarb antitrust courts should treat the professional self-regulation defense when conduct complained of otherwise would be a per se violation. Varying approaches to this issue have been suggested by lower courts and commentators. One tactic would be to treat all such cases under the rule of reason. ${ }^{94}$ This approach, however, seems overly favorable to professional interests. A mere claim of professional self-regulation would impose upon a plaintiff the burden of proving specific bad intent or effects, notwithstanding the fact that offenses of a per se nature previously have been judged to be so pernicious and of such destructive effect that they may be banned without this proof. ${ }^{95}$

One court, in Veizaga v. National Board for Respiratory Therapy, ${ }^{96}$ and one commentator, Douglas Rigler, ${ }^{97}$ have proposed closely related "two-step" analyses that attempt to provide a more balanced considera-

(1965); Corleto v. Shore Memorial Hosp., 138 N.J. Super. 302, 350 A.2d 534 (1975); Fiorentino v. Wenger, 19 N.Y.2d 407, 227 N.E.2d 296 (1967).

92. For an earlier antitrust case indicating judicial unwillingness to question subjective standards governing "social" as opposed to "commercial" behavior, see Hughes Tool Co. v. Motion Picture Ass'n, 66 F. Supp. 1006 (S.D.N.Y. 1946). But see Feminist Women's Health Center, Inc. v. Mohammad, 415 F. Supp. 1258, 1270 (N.D. Fla. 1976), rev'd on other grounds on rehearing, No. TCA 75-186 (N.D. Fla. Nov. 18 \& Dec. 3, 1976) (now on appeal to the Fifth Circuit Court of Appeals).

93. Compare the judicial deference shown to professional judgment in cases that have questioned on due process grounds the unreasonableness of hospital standards governing physician admitting privileges. See, e.g., Sosa v. Board of Managers, 437 F.2d 173, 176 (5th Cir. 1971).

94. See Boddicker v. Arizona State Dental Ass'n, 549 F.2d 626 (9th Cir.), cert. denied, 434 U.S. 825 (1977); Bauer, Professional Activities and the Antitrust Laws, 50 Notre DAme LAw. 570, 584-92 (1975); Tyler, Goldfarb v. Virginia State Bar: The Professions are Subject to the Sherman $A c t, 41$ Mo. L. Rev. 1, 10-12 (1976).

95. See Feminist Women's Health Center, Inc. v. Mohammad, 415 F. Supp. 1258, 1263 (N.D. Fla. 1976), rev'd on other grounds on rehearing, No. TCA 75-186 (N.D. Fla. Nov. 18 \& Dec. 3, 1976) (now on appeal to the Fifth Circuit Court of Appeals).

96. [1977-1] TRADE CASEs (CCH) I 61,274 (N.D. Ill. Jan. 27, 1977).

97. Rigler, Professional Codes of Conduct After Goldfarb: A Proposed Method of Antitrust Analysis, 29 ARK. L. REv. 185 (1976). 
tion of the conflicting interests served by competition and professional regulation. The first step is to determine whether the challenged activity is "commercial" or "noncommercial" in its nature and character. ${ }^{98}$ The second step under Veizaga is to apply relevant per se rules to commercial activities but only a rule of reason analysis to noncommercial ones, even if the alleged restraint is of a per se nature. ${ }^{99}$ Rigler also would apply per se rules to commercial activities, although he would exempt wholly "noncommercial" professional activities from Sherman Act jurisdiction. ${ }^{100}$ The obvious problem presented by these approaches is the potentially mechanical and perhaps unmanageable distinction that they would draw between "commercial" and "noncommercial" activities. It is not clear for example, into what category hospital decisions to grant staff privileges or enact medical procedure by-laws would fall.

A third, preferable-way to relate per se rules and professional selfregulation interests was employed in a Florida district court's first decision in Feminist Women's Health Center, Inc. v. Mohammad. ${ }^{101}$ In this case an outpatient abortion center sought relief from an alleged boycott by fee-for-service obstetricians that had deprived the center of physicians and back-up services at the local hospital. In ruling on plaintiff's motion for a preliminary injunction, the district court held that the plaintiff could rely on its complaint of a per se violation unless the defendants established that their professional self-regulation measures had been carried out in "good faith."102 The court stated the good faith test to be "whether the defendants were motivated by a bona fide concern over medical or ethical standards rather than by an anticompetitive animus" 103 and held that defendants were not likely to satisfy this test. The court relied chiefly on the substantial difference in fees charged for abortions by the center and by defendant obstetricians, the uncertainty of medical standards concerning appropriate abortion services, and the failure of defendants to undertake any "thoroughgoing inquiry" concerning the quality of care rendered at the center. ${ }^{104}$ This

98. Id. 189-91.

99. [1977-1] TRADE CASES (CCH) ๆ 61,274, at 70,870.

100. Rigler, supra note 97 , at $189-90$.

101. 415 F. Supp. 1258 (N.D. Fla. 1976). This decision subsequently was modified by two other orders that resulted in a dismissal prior to trial on other grounds. No. TCA 75-186 (N.D. Fla. Nov. 18 \& Dec. 3, 1976) (now on appeal to the Fifth Circuit Court of Appeals).

102. 415 F. Supp. at 1269.

103. Id.

104. Id. at 1270. This court's demand for a "thoroughgoing inquiry" by defendants parallels the Washington Supreme Court's approach to the professional self-regulation issue in Group Health Coop. v. King County Soc'y, 39 Wash. 2d 586, 606-14, 237 P.2d 737, 748-54 (1951).

In two subsequent decisions the Florida district court modified its good faith test to take into 
approach has the merit of focusing on specific justifications for professional self-regulation and avoiding an overly general inquiry into "commercial" versus "noncommercial" essences of professional activities. It also seems quite similar if not identical to the suggested twostep approach for analyzing anti-HMO boycott behavior by physicians. In the case of classic boycotts and other similar conduct to which a per se rule should ordinarily apply, it would seem unlikely that defendants could satisfy the Feminist Women's preliminary good faith test.

2. Conscious Parallelism. Many of the restraints available for use against HMOs, such as the denial of access to consultation-referral networks ${ }^{105}$ and the exercise of social disapproval or ostracism against HMOs and their physicians, can be undertaken on an independent basis by individual fee-for-service physicians. These practices will have a particularly damaging effect only if all or most physicians in the community follow them. It may happen, however, that many physicians do engage in these practices with the awareness that other physicians are involved but that there is no direct evidence of an agreement among the physicians to act in concert or even of a proposal for joint action. Since section 1 of the Sherman Act requires the finding of some "contract . . . combination or conspiracy,"106 any antitrust attack on this behavior is likely to face great difficulty in establishing the existence of an agreement by inference from circumstantial evidence. ${ }^{107}$ In

account a Noerr-Pennington claim by the defendants that their communications implementing the alleged boycott had been made within and to "public agencies." Feminist Women's Health Center, Inc. v. Mohammad, No. TCA 75-186 (N.D. Fla. Nov. 18 \& Dec. 3, 1976) (now on appeal to the Fifth Circuit Court of Appeals). The Noerr-Pennington doctrine is discussed in text accompanying notes 114-18 infra. The court held that the effect of such a claim is to switch the burden of proof back to the plaintiff, who must then show that the communications to public agencies were a "sham" and not intended to seek public agency action. Feminist Women's Health Center, Inc. v. Mohammad, No. TCA 75-186, at 3 (N.D. Fla. Nov. 18, 1976). The court then found that the plaintiff had not satisfied this burden and dismissed the action prior to trial. Feminist Women's Health Center, Inc. v. Mohammad, No. TCA 75-186, at 5-8 (N.D. Fla. Dec. 3, 1976). While the potential for success of a defense based on Noerr-Pennington in this situation certainly is significant, it does not detract from the value of Feminist Women's approach to balancing per se complaints and professional self-regulation claims.

105. The denial of HMO access to consultation-referral networks among fee-for-service physicians may harm both smaller HMOs, which do not employ their own specialists, and the fee-forservice practice of part-time HMO physicians.

106. 15 U.S.C. $\S 1$ (1976).

107. This kind of behavior by individual physicians, who arguably possess monopoly power, might be analogized to the exclusionary conduct by monopolists or incipient monopolists that is prohibited by section 2 of the Sherman Act. 15 U.S.C. \& 2 (1976). See Havighurst, HMOs 776 n.181. This alternative approach does not seem viable, however, in view of the courts' traditional focus in monopoly cases on very large market shares possessed by single producers, $i d$., the fact that this behavior by an individual physician will have only a relatively small effect on the HMO, and the difference between ordering a corporation and an individual to serve all comers. 
this situation courts require some evidence in addition to consciously uniform behavior to allow the fact finder to infer the existence of an agreement. ${ }^{108}$ This additional evidence must be sufficient to support a plausible inference that the conduct complained of would not have occurred but for an agreement among the defendants.

In the case of fee-for-service physicians acting adversely to an HMO's interest, the following analysis might be employed to support a rational inference of agreement. If a relatively large number of physicians are engaged in these activities, it may be argued that many of them individually would not have risked the economic loss from refusing to deal, or the possible social loss from appearing to be a public critic of others' work, without some understanding that all or most of their professional colleagues were going to be similarly engaged. As noted, economic gains to fee-for-service physicians will not accrue without relatively uniform behavior, although this point seems stronger for refusals to consult with and refer to HMOs and their physicians than for social disparagement of HMO operations. Additionally, the involvement of a relatively large number of fee-for-service physicians may help negate the competing explanation that the uniform behavior results from rationally interdependent but non collusive decisions by oligopolists. ${ }^{109}$

The above argument seems rather weak, however, in view of several special circumstances involved with medical practice. Individual physicians are not only economically calculating "business firms" but also moral actors, who quite understandably may believe uniformly but independently that prepaid medical practice is "wrong" and "bad" for the public. ${ }^{110}$ These beliefs may make physicians willing to risk some economic loss by independent action; moreover, in view of physicians' generally high incomes, ${ }^{111}$ any economic loss may be quite bearable.

108. See Theatre Enterprises, Inc. v. Paramount Film Distrib. Corp., 346 U.S. 537, 541 (1954); C-O Two Fire Equip. Co. v. United States, 197 F.2d 489 (9th Cir.), cert. denied, 344 U.S. 892 (1952).

109. A competing explanation of oligopolistic interdependence also may be overcome by a showing that identical behavior by oligopolists required a relatively complex form of behavior, with substantial risks to the individual firm if others do not go along. See, e.g., Interstate Circuit, Inc. v. United States, 306 U.S. 208 (1939); C-O Two Fire Equip. Co. v. United States, 197 F.2d 489 (9th Cir.), cert. denied, 344 U.S. 902 (1952). The behavior in our case, however, appears to be quite simple and would not involve overwhelming loss to any individual physician if others fail to go along.

110. See text accompanying notes $21-23$ supra .

111. The AMA's 1973 estimates for average net incomes of physicians by specialty range from a little over $\$ 40,000$ for pediatricians and general practitioners to more than $\$ 59,000$ for surgeons. D. Hapgood, The Screwing of THE AVerage Man 129 (1974). Of course it is the former categories of physicians who stand to lose most from HMO competition, and perhaps $\$ 40,000$ is not enough. 
Furthermore, widespread moral beliefs among fee-for-service physicians may allow individual physicians to act interdependently, but yet independently, as rational "oligopolists," despite the presence of a much larger number of competitors than is usual. These arguments suggest that independent or interdependent explanations of consciously uniform behavior against HMOs and their physicians are just as plausible as an "agreement" to act in concert. Finally, the breadth and intensity of fee-for-service physicians' moral beliefs about HMOs may be enhanced by communications among physicians that are protected for first amendment reasons. ${ }^{112}$ In general, therefore, it may be inappropriate to rely on communications among physicians about the "evils" of HMOs and on how individual physicians are responding or ought to respond as evidence from which one may infer a specific agreement to act in a concerted fashion. ${ }^{113}$ If these arguments are sound, "conscious parallelism" may be a good defense to many antitrust attacks against common but noninstitutional behavior by physicians directed against HMOs.

3. Protected Communications. Two kinds of organized communication by and among fee-for-service physicians might be used to strengthen physicians' resolve to act against HMOs and to help create a negative image of HMOs with the public. The issue raised by each type of communication is whether first amendment values are strong enough to protect the organized communication itself from antitrust attack as an unreasonable restraint of trade.

Under the Noerr-Pennington doctrine ${ }^{114}$ individuals may combine to seek governmentally-imposed restraints upon their competitors without violating the antitrust laws, as long as their combination does not constitute a "mere sham." 115 This doctrine clearly protects a wide

112. See text accompanying notes 114-22 infra .

113. In other situations communications among competitors about prices (accompanied by exhortations that a certain common price level will be advantageous to all) or about relatively complex forms of behavior may be used to support the inference of an agreement to act in concert. See, e.g., Interstate Circuit, Inc. v. United States, 306 U.S. 208 (1939); American Column \& Lumber Co. v. United States, 257 U.S. 377 (1921).

114. See UMW v. Pennington, 381 U.S. 657, 670 (1965); Eastem R.R. Presidents Conference v. Noerr Motor Freight, Inc., 365 U.S. 127 (1961).

115. See Eastern R.R. Presidents Conference v. Noerr Motor Freight, Inc., 365 U.S. 127, 144 (1961). The sham exception does limit this doctrine's scope, at least to the extent that it does not protect violations of other laws from antitrust attack, see. P. AREEDA, ANTITRUST ANALYsIS II 393(e), 394 (2d ed. 1974), such as the abuse of judicial process by making repetitive, unfounded claims, see California Motor Transp. Co. v. Trucking Unlimited, 404 U.S. 508 (1972), or deliberate submission of false information to public officials, see Woods Exploration \& Producing Co. v. Aluminum Co. of America, 438 F.2d 1286 (5th Cir.), cert. denied, 404 U.S. 1047 (1971); Harman v. Valley Nat'l Bank, 339 F.2d 564 (9th Cir. 1964). 
range of speech that may be intended to have an ultimate effect upon legislatures or administrative agencies, but that also harms competitors.

The Noerr-Pennington doctrine seems to offer relatively broad protection from antitrust law for both private and public dissemination by physician groups of anti-HMO propaganda that has "incidental" sideeffects of encouraging common physician behavior against HMOs or disparaging HMOs with the public. ${ }^{116}$ The widespread nature of government regulation over $\mathrm{HMOs}^{117}$ and medical practice in general should offer ample opportunities for legitimate attempts to influence legislatures or administrative agencies responsible for enforcing existing laws. Moreover, the vulnerability of HMOs to the potential charge of over-economizing ${ }^{118}$ may make them relatively easy targets for criticism that avoids violating other laws and therefore the sham exception to Noerr-Pennington.

Apart from organized efforts to seek governmental restraints, the exchange of information and opinions about HMOs among fee-forservice physicians presents a more difficult and perhaps novel question of balancing first amendment and antitrust concerns. Suppose, for example, that in a series of meetings one or more physicians inform others of the reasons why they are refusing to cooperate with HMOs. Suppose also that these meetings are followed by relatively uniform noncooperation with HMOs and their physicians.

On the one hand, this exchange and the subsequent behavior might be viewed as similar to the situation where a trade association meeting at which a firm or firms announce new prices and give reasons for the change is followed by uniform price increases. This exchange can help justify the inference of an agreement to fix prices, ${ }^{119}$ or in some cases the exchange itself may be banned as an unreasonable restraint because of its likely anticompetitive effects. ${ }^{120}$

On the other hand, our physician exchanges might be characterized as the expression of reasons why physicians should individually make certain moral judgments and undertake consequent actions that would benefit society. ${ }^{121}$ Under this view, there seem to be significant differences between the exchange of price information and the ex-

116. For an interesting example of such propaganda, see HMOs versus Ethical Medicine: Hearings on H.R 51 and H.R. 4871 Before the Subcomm on Public Health and Environment of the House Comm. on Interstate and Foreign Commerce, 93d Cong., 1st Sess. 265-74 (1973) (statement of Thomas G. Dorrity).

117. See notes $47-48$ supra.

118. See text accompanying note 21 supra.

119. See American Column \& Lumber Co. v. United States, 257 U.S. 377 (1921).

120. See United States v. Container Corp. of America, 393 U.S. 333 (1969).

121. The following analysis and its distinction between "reasons" and "means" is suggested by Professor Scanlon's theory of first amendment protection for certain forms of harmful speech. 
change of reasons for anti-HMO acts. The exchange of price information can have only the purpose of inviting others to follow suit; if they do not, the speaker will withdraw his price increase for sensible, commercial reasons. The speaker in this situation is only providing others with the means they need to engage in an illegal act, and there is no strong reason to provide first amendment protection for this form of speech. One cannot as easily infer, however, an illegal purpose for our physician speakers. They simply may be giving reasons for actions they are taking themselves, and will continue to take whether or not their colleagues follow. In this situation, though the speech may have harmful effects, the speakers are not responsible for the effects and thus first amendment protection for their speech seems appropriate. ${ }^{122}$

4. General Impact of Professional Restrictions. In concluding this discussion of professional restrictions on HMOs, it may be noted that the "more subtle" forms of anticompetitive behavior which seem likely to survive antitrust scrutiny will be less efficient means of opposition than the concerted refusals to deal which were earlier declared illegal. ${ }^{123}$ The efficacy of these "new" forms of opposition will depend largely upon the intensity and prevalence of unfavorable attitudes towards HMOs among fee-for-service physicians and the risk of loss to individual physicians from refusing to deal, factors which may vary greatly over place and time. Nonetheless, the most significant effect of this more scattered and less formal opposition may be a very general one. Physicians, particularly new ones just starting a career, may hesitate to join an HMO because of the potential risk of future damage to their reputations and careers, however slight the risk may in fact be. ${ }^{124}$

\section{Price Discrimination by Hospitals.}

In addition to restrictions on hospital admitting privileges and bylaws, non-hospital-based HMOs may suffer a competitive disability because of unfairly high prices for hospital services that they must

See Scanlon, A Theory of Freedom of Expression, in 1 Philosophy \& Pub. Affairs 204 (1972), reprinted in THe PHILOSOPHY OF LAW 153 (R. Dworkin ed. (1977)).

122. Id. 159-60. For a broader and more detailed discussion of this issue, see Havighurst, Professional Restraints on Innovation in Health Care Financing, 1978 Duke L.J. 303, 355-60. Professor Havighurst would give more weight to antitrust concerns about the harmful effect of such physician speech than the author has suggested. See id.

123. See notes 30-35 supra and accompanying text.

124. On the importance of personal reputation and contacts for career development by young physicians, see Hall, Stages in a Professional Career, in Professionalization 87 (H. Vollmer \& D. Mills eds. 1966).

In the early 1970 s physician recruitment was considered the fourth most significant barrier (after capital requirements, access to employers and opposition from other providers) to HMO growth. See McNeil \& Schlenker, supra note 12, at 200 . This could be explained by the different 
purchase in order to provide comprehensive insurance. ${ }^{120}$ In this section two different settings in which this price discrimination might occur are considered. The application of substantive antitrust law to these situations is then examined, and finally the potential applicability of the Parker v. Brown ${ }^{126}$ doctrine as a jurisdictional defense is discussed.

Hospitals with substantial market power may view the HMO as an actual competitor to their own (or their physicians') outpatient services or to their own HMOs. ${ }^{127}$ They also may fear the HMO as a potential competitor in the provision of inpatient care. These hospitals might charge HMOs prices that are greater than the hospitals' costs of serving HMO inpatients in three different ways. First, they could refuse to negotiate special rates with an HMO that has the capability of providing some ancillary inpatient services. Second, hospitals with their own HMOs might subsidize them by shifting some HMO costs onto all other patients, including those of the non-hospital-based HMO. ${ }^{128}$ Finally, and most likely, hospitals could discriminate by refusing to give an HMO the same discount that many Blue Cross plans are able to obtain for their subscribers. ${ }^{129}$ This latter method, and the possible reasons for it, merge into the second situation in which non-hospitalbased HMOs may face unfair price discrimination by hospitals.

Non-hospital-based HMOs, and commercial indemnity plans as well, may be harmed indirectly by the manner in which nonprofit community hospitals arrange to collect their revenues. In many parts of the country these hospitals and Blue Cross plans negotiate special "rates" or "costs" for hospital services provided to Blue Cross subscribers. ${ }^{130}$ The hospitals then attempt to cover "other costs" by setting uniform charges that apply to all other fee-paying patients. ${ }^{131}$ The joint nature of many hospital costs necessarily makes the relationship between the Blue Cross rate and the "costs" of serving Blue Cross subscribers an imprecise one. Furthermore, Blue Cross often will have substantial buying power vis-à-vis individual hospitals and a general incentive to keep its own costs down, whether from competition with

forms and apparently somewhat lower economic rewards (in which additional risk might be a significant factor) provided by HMOs to their physicians. See Note, supra note 2, at 946-49.

125. For examples of HMOs trying to obtain a lower hospital rate equal to that obtained by Blue Cross, see FTC REPORT 58, 65, 67, 70.

126. 317 U.S. 341 (1943).

127. See Havighurst, HMOs 760-66.

128. Id. $760-61$.

129. See note 125 supra. Cf. Travelers Ins. Co. v. Blue Cross, 481 F.2d 80 (3d Cir.), cert. denied, 414 U.S. 1093 (1973) (commercial health insurer complaining of same problem).

130. See notes 125 \& 129 supra.

131. See Travelers Ins. Co. v. Blue Cross, 481 F.2d 80, 83-84 (3d Cir.), cert. denied, 414 U.S. 1093 (1973). 
other insurers or regulatory pressure. The combined factors suggest that in many situations hospital rates to Blue Cross may understate the fair costs of serving Blue Cross subscribers and result in overstated costs to other patients.

In Travelers Insurance Co. v. Blue Cross, ${ }^{132}$ a commercial insurer complained that Blue Cross-hospital reimbursement rates had unreasonably shifted hospital costs from Blue Cross subscribers to other feepaying patients. Specifically, the Blue Cross contracts had eliminated from costs attributable to Blue Cross subscribers all expenses of hospital construction, free care for indigent patients and losses from patient defaults on payments. ${ }^{133}$ Travelers established at trial that the consequence of this shifting was that hospitals, in order to collect revenues that covered their total expenses, were charging policyholders of commercial health insurers an average of fourteen to fifteen percent more for hospital services than was charged Blue Cross policyholders. ${ }^{134}$

Non-hospital-based HMOs would seem to deserve at least the same treatment from hospitals that Blue Cross receives. HMO inpatients are no more responsible for a hospital's welfare costs or default losses than Blue Cross subscribers and, however capital costs are to be treated, there would seem to be no distinction between these two kinds of patients. Yet the lesser bargaining power of HMOs combined with hospitals' need to cover all their expenses could result in higher charges to HMOs.

1. The Application of Price Discrimination Law. The provisions of federal antitrust law that explicitly prohibit price discrimination, the Robinson-Patman Act, ${ }^{135}$ do not apply to the hospital-HMO situation because of the Act's limitation to sales of "commodities" that are made "in" interstate commerce. ${ }^{136}$ Nonetheless, price discrimination against HMOs by hospitals with substantial market power may be amenable to attack under section 2 of the Sherman Act as monopolizing conduct. In certain circumstances other cases of price discrimination by hospitals might be held to constitute a restraint of trade under section 1 or a conspiracy to monopolize under section 2.

Where inpatient services to HMOs are unfairly priced by hospitals that have market shares and other characteristics sufficient to establish

132. 481 F.2d 80 (3d Cir.), cert. denied, 414 U.S. 1093 (1973).

133. 481 F.2d at 82 .

134. Travelers Ins. Co. v. Blue Cross, 361 F. Supp. 774, 776 (W.D. Pa. 1972).

135. 15 U.S.C. $\& 13$ (1976).

136. Id. \& 13(a). 
their monopoly power, ${ }^{137}$ the price discrimination may be characterized as conduct by a monopolist that has the purpose or likely effect of excluding actual or potential competition. ${ }^{138}$ In other words, the price discrimination may be viewed as an illegal attempt by the hospital either to protect its monopoly power over inpatient care, by increasing barriers to entry, or to use monopoly power in the inpatient market to protect and expand the hospital's power in the market for outpatient services. ${ }^{139}$

As Professor Havighurst has noted, ${ }^{140}$ this conclusion may be strengthened by comparing the hospital-HMO situation to that of a "price-squeeze" by a vertically integrated monopolist, which was held to violate section 2 of the Sherman Act in United States v. Aluminum Co. of America. ${ }^{141}$ Price squeezing involves a vertically integrated firm with monopoly power over product $X$, which it uses to make product $Y$ and sells to other producers of $Y$. This firm can "squeeze" its competitors out of business in $Y$ by decreasing the margin between its sale price on $X$ and its own price on $Y$ to an unprofitable level. By analogy, the price discriminating hospital may be viewed as both selling its inpatient services (product $X$ ) to the non-hospital-based HMO and using its inpatient services as part of more comprehensive services (product $Y$ ) that both the hospital and HMO offer to the public. This analogy certainly is more apt where the hospital operates its own HMO, ${ }^{142}$ but it also seems to offer some precedential support for the more general situation of price discrimination by monopoly hospitals. ${ }^{143}$

Where the price discriminating hospital lacks substantial market power, it will be more difficult to show antitrust violations by the hospital. For example, where Blue Cross has obtained a discount by reason of its own buying power, the hospital may in fact need to price its other services at a higher level in order to cover total costs. In this case the antitrust attack should be against Blue Cross rather than the hospital, a

137. On establishing the existence of a firm's monopoly power for purposes of section 2 analysis, see L. Sullivan $\$ \$$ 5-32.

138. See $i d . \S 47(\mathrm{~d})$ for a discussion on the use of price discrimination by monopolists generally as an exclusionary tactic.

139. See United States v. Griffith, 334 U.S. 100 (1948); United States v. United Shoe Mach. Corp., 110 F. Supp. 295, 340-41, 349 (D. Mass. 1953), aff'd per curiam, 347 U.S. 521 (1954).

140. Havighurst, HMOs 761-63.

141. 148 F.2d 416, 436-38 (2d Cir. 1945).

142. Professor Havighurst applied this analogy only to this situation. Havighurst, HMOs 760-66.

143. The general situation is more likely to occur if hospitals continue to show little interest in developing their own HMOs. As of 1976 , only seven hospitals were sponsors of HMOs. FTC REPORT 115-16. 
possibility which is discussed in the next section. ${ }^{144}$ In any event, on these facts the only antitrust claim available against the hospital would be an attempt to monopolize charge under section 2 of the Sherman Act, and this is likely to fail because of the absence of any specific intent to obtain monopoly power. ${ }^{145}$ Another possible antitrust situation may occur when a hospital acting in its role of agent for its fee-forservice medical staff initiates price discrimination against non-hospitalbased HMOs. Obtaining evidence to establish the existence of such a combination may be very difficult, but if the evidence is available the price discrimination could be condemned as either a restraint of trade under section 1 or a conspiracy to monopolize under section 2 .

Note that condemning price discrimination against non-hospitalbased HMOs will raise the objection that the remedy of enforcing a "fair" price for the HMO will turn the antitrust court into a public utility commission, with the continuous need to assess the full range of changing hospital costs and what part should be allocated to the HMO. ${ }^{146}$ The problem of administering "fair" hospital prices for HMOs would seem to be a formidable one, ${ }^{147}$ except where Blue Cross is already obtaining a discount for its subscribers. ${ }^{148}$ In this situation the court simply could rule that the HMO is prima facie entitled to the Blue Cross rate and place the burden on the hospital to prove any additional costs that fairly should be allocated to HMO patients. In other situations, which may not be very frequent, the better approach may be to recognize the theoretical nature of the objection and to trust that the initial court order will produce relatively amicable negotiations as to price between the HMO and hospital. ${ }^{149}$

2. Parker v. Brown Defenses. In several situations price discriminating hospitals may be able to raise, as a jurisdictional defense, the Parker doctrine that antitrust laws do not apply to anticompetitive acts of state governments. ${ }^{150}$ First, several states have established public regulation of all hospital rates ${ }^{151}$ or, under HMO enabling statutes,

144. See text accompanying notes 178-315 infra.

145. See Swift \& Co. v. United States, 196 U.S. 375, 396 (1905).

146. See United States v. United Shoe Mach. Corp., 110 F. Supp. 295, 349 (D. Mass. 1953), affd per curiam, 347 U.S. 521 (1954); C. KAYSEN \& D. TURNER, ANTITRUST POLICY 125-27 (1959).

147. See Havighurst, HMOs 762.

148. See text accompanying notes 129-34 supra.

149. See C. KAYSEN \& D. TURNER, supra note 146 , at 127.

150. See Parker, 317 U.S. at 350-52. See generally Blumstein \& Calvani, State Action As A Shield and $A$ Sword In A Medical Services Antitrust Context: Parker v. Brown In Constitutional Perspective, 1978 Duke L.J. 389.

151. See Lewin, Somers \& Somers, State Health Cost Regulation: Structure and Administration, 6 U. TOLEDO L. REV. 647, 658 (1975). 
have provided for state regulation of hospital-HMO rates. ${ }^{152}$ These laws provide non-hospital-based HMOs with an alternative and probably exclusive forum in which to challenge unfair price discrimination by hospitals. Should a state agency approve price discrimination against HMOs under either of these kinds of laws, the discriminating hospital would appear to have a good Parker defense even as this defense has been refined and narrowed by the Supreme Court's recent decisions in Goldfarb ${ }^{153}$ and Cantor v. Detroit Edison Co. ${ }^{154}$

In Goldfarb the Court held that anticompetitive activity by either a "state agency"155 or a private organization must be "required by the State acting as sovereign" before the Parker defense can apply. ${ }^{156}$ Activities that merely "complemented" or were "prompted" by a regulatory scheme did not satisfy this threshold test. ${ }^{157}$ In Cantor the Court held that the Parker defense did not apply to an electric power company's free distribution of light bulbs, even though costs of the distribution program were included in the company's tariff which the state regulatory commission had approved, and compliance with which was required until a new tariff was approved. A majority of the Court ${ }^{158}$ justified this decision on grounds that the defendant power company could prove neither that the state had played a "dominant" role in the decision to approve inclusion of light bulb costs within the tariff ${ }^{159}$ nor that the regulatory action was "necessary" to accomplish the purposes of Michigan's act to regulate the electric power industry. ${ }^{160}$ As stated by the Court, the second part of this test is that the antitrust exemption must be "necessary to make the regulatory act work and even then only to the minimum extent necessary," which is the same test that is used by antitrust courts for an implied antitrust immunity under federal regulatory statutes. ${ }^{161}$

Cantor's incorporation of a "necessity" test into the Parker doctrine appears to invite antitrust courts to second guess state regulatory

152. See Kissam \& Johnson, State HMO Laws 53.

153. 421 U.S. at $788-93$.

154. 428 U.S. 579 (1976). See also Bates v. State Bar of Ariz, 433 U.S. 350 (1977).

155. The "state agency" in Goldfarb was the Virginia State Bar Association, which was organized by state law to serve as an administrative arm of the Virginia Supreme Court. 421 U.S. at $776 \mathrm{n.2}$.

156. Id. at 587 .

157. Id.

158. Justice Stevens delivered the opinion of the Court. Justices Brennan, Marshall and White joined in the opinion, and Chief Justice Burger joined in the part under discussion here. 428 U.S. at 581. In addition, Justice Blackmun's concurring opinion, id. at 605-14, employs a preemption doctrine analysis that is similar to that discussed in the text.

159. Id. at 592-95.

160. Id. at 595-98.

161. Id. at 596-97. 
decisions. ${ }^{162}$ Yet future applications of the necessity test in Parker situations may and arguably should be carefully limited to factual situations like those in Cantor. In holding that the state regulatory action concerning light bulb distribution was not necessary to implement effective regulation of the electric power industry, the Court seems to have relied heavily on the unregulated nature of the light bulb market and the state agency's lack of expertise or statewide policy regarding free light bulb distributions and their relation to electric power sales. ${ }^{163}$ Cantor's rationale thus can be characterized as the refusal to extend Parker immunity to peripheral state regulatory action for which no rational justification is offered by the state. Reading Cantor in this narrow way would appear appropriate for three reasons: the present Court's apparent propensity for narrow readings of prior cases, ${ }^{164}$ the policy of keeping antitrust courts out of direct public utility regulation $^{165}$ and the need to preserve room for state regulatory operations under our constitutional principle of federalism. ${ }^{166}$

If Cantor is so limited, state agency approval of price discrimination by hospitals against HMOs should obtain Parker protection. ${ }^{167}$ This state approval, with the typical requirement that the approved rate be followed until changed, would appear to satisfy Goldfarb's preliminary test for some state command. ${ }^{168}$ In addition, the close relationship between the approved rate and the state's regulation of all hospital rates or all hospital-HMO dealings should satisfy Cantor's qualified "necessity" test. ${ }^{169}$

162. Cantor in effect employs preemption doctrine analysis to limit the scope of the Parker doctrine. For a taste of the academic debate prior to Cantor on the advisability of such a shift, compare Posner, The Proper Relationship Between State Regulation and the Federal Antitrust Laws, 49 N.Y.U.L. Rev. 693 (1974) and Note, Parker v. Brown: A Preemption Analysis, 84 YAle L.J. 1164 (1975) with Handler, The Current Attack on the Parker v. Brown State Action Doctrine, 76 Colum. L. Rev. 1 (1976) and Verkuil, State Action, Due Process and Antitrust: Reflections on Parker v. Brown, 75 Colum. L. Rev. 328 (1975).

163. See 428 U.S. at 584-85, 595-98.

164. For a good example, see the Cantor Court's reading of Parker. Id. at 585-92.

165. See, for example, text accompanying notes 146-49 supra.

166. See Verkuil, supra note 162. My own preference for this "federalism" approach is based on the value of giving weight to constraining constitutional principles in "hard cases" of statutory interpretation. See note 71 supra. Of course, the competing "preemption" approach, see note 162 supra and accompanying text, rests fundamentally on another constitutional principle, the supremacy clause, but it seems appropriate to give this competing principle weight only when Congress has indicated some intent for a particular statute to limit state action. The legislative history of the Sherman Act provides no such indication. See Parker, 317 U.S. at 350-51. See also Blumstein \& Calvani, supra note 150, at 395-431, where more weight is given to the supremacy clause than to the federalism principle.

167. Professors Blumstein and Calvani might arrive at the same result under their broader reading of Cantor. See Blumstein \& Calvani, supra note 150, at 424-28.

168. See text accompanying notes $156-57$ supra.

169. Cantor arguably may be interpreted as requiring both a "dominant" state role in the 
Second, public hospitals also might try to defend price discrimination under the Parker doctrine on the theory that their price discrimination is state-authorized as part of their general authority to operate a monopoly public service. ${ }^{170}$ The Supreme Court's recent decision in City of Lafayette v. Louisiana Power \& Light Co. ${ }^{171}$ suggests, however, that this defense will be a difficult one to maintain. In this case five justices rejected an argument by municipally-owned public utilities that the Parker doctrine exempts all anticompetitive acts by political subdivisions of a state. Four justices concluded that the Parker exemption applies only if the state has "authorized or directed" anticompetitive conduct by a political subdivision. ${ }^{172}$ Such authority need not be "specific" or "detailed" and may exist "when it is found from the authority given a governmental entity to operate in a particular area, that the legislature contemplated the kind of activity complained of."173 Chief Justice Burger concurred in the Court's judgment, but he relied on the different theory that the Parker exemption should not apply automatically to "proprietary" activities of political subdivisions. ${ }^{174}$ Price discrimination by public hospitals probably would be subject to antitrust scrutiny under either of these tests. Price discrimination is not logically connected to hospital operations, and thus legislatures are not likely to have "contemplated" price discrimination while authorizing public hospitals. Additionally, the fact that private entities operate hospitals suggests, at least for antitrust purposes, that public hospitals would be classified as "proprietary" enterprises under the Chief Justice's approach. ${ }^{175}$

Third, some states have chosen to regulate hospital rates in a selective manner, providing state agency review only for hospital rates to

regulation (which might not be present in the price discriminating hospital situation) and a showing of "necessity" in order for the Parker defense to apply. See L. Sullivan § 238a. However, the Court's opinion in Cantor treated these two issues as providing "quite different reasons" for an antitrust immunity, 428 U.S. at 592, which suggests that either condition is sufficient for Parker to apply.

170. See City of Lafayette v. Louisiana Power \& Light Co., 98 S. Ct. 1123 (1978).

171. $I d$.

172. Id. at 1137.

173. Id. at 1138 .

174. Id. at 1139 .

175. The Chief Justice's concurring opinion does not contain a clear antitrust test for "proprietary" governmental activities, but it does suggest that if competitors of the municipal enterprise may be subjected to antitrust claims then the municipal enterprise also ought to be subject to similar claims. Id. at 1140. Cf. Note, The Antitrust Liability of Municipalities Under the Parker Doctrine, 57 Boston L. Rev. 368, 384-86 (1977) (using an approach similar to that of the Chief Justice and arguing that proprietary municipal enterprises should be those providing the same kinds of services as private entities and capable of aggregating and exercising the kinds of power which, in the private sector, are the concern of antitrust law). 
Blue Cross and/or the state Medicaid program. ${ }^{176}$ In this situation a hospital that grants a rate discount to Blue Cross but not to an HMO might attempt to defend its rate structure under the Parker doctrine as behavior required in effect by a command of the state rate agency. It certainly is conceivable that particular hospitals may be forced into a discriminatory rate structure because of selective rate review by a state agency. Moreover, in theory at least the HMO would have access to the state regulatory agency for redress of the situation. Nonetheless, the state command in this case does not apply directly to the hospitalHMO rate negotiation, and in view of the recent narrowing of the Parker doctrine this defense most likely should and would be rejected. ${ }^{177}$

\section{Restrictive Activities by Insurance Companies .}

Blue Cross and Blue Shield plans, with their relatively large market shares to protect, ${ }^{178}$ and defensive HMOs, which are employed to protect the interests of their fee-for-service sponsors, ${ }^{179}$ might engage in a variety of anticompetitive acts toward other HMOs. ${ }^{180}$ Three kinds of anticompetitive acts seem most likely: refusals by Blue plans to supply certain services to HMOs or their physicians, various types of anticompetitive pricing and the formation of defensive HMOs with an intent to exclude or deter competition by more aggressive ones. In this section, the issue of assessing the market power of the Blues and defensive HMOs will be considered. The application of antitrust law to the three types of anticompetitive behavior will then be analyzed, followed by a discussion of two jurisdictional defenses that may be raised to protect some of these acts.

176. See Lewin, Somers \& Somers, supra note 151, at 658.

177. Selective hospital rate review also may be effected indirectly by state regulation of Blue Cross plans and their negotiations with hospitals for subscriber rates. Id. This review might "force" hospitals to discriminate against non-hospital-based HMOs. See text accompanying notes 125-34 supra. A hospital might try to defend its action under the McCarran-Ferguson Act antitrust exemption for state regulated insurance activities by claiming that its high price to an HMO is both part of the insurance business and in effect required by state regulation (of Blue Cross and possibly the HMO as well). By analogy to the Parker issue discussed in the text, this claim probably should and would be rejected because the state regulation in question does not apply to the hospital-HMO rate. Cf. Ohio v. Ohio Medical Indem., Inc. [1976-2] TRADE Reg. REP. (CCH) I 61,128 (S.D. Ohio, Sept. 16, 1976) (a McCarran-Ferguson claim by a state medical society that owned a Blue Shield plan rejected).

178. See J. KRIZAY \& A. WILson, supra note 19 , at 3.

179. See text accompanying notes $18-19$ supra.

180. Commercial insurers might engage in these acts as well, but these companies typically have relatively small market shares in particular communities, see J. KRIZAY \& A. WilsoN, supra note 19, at 3, and they are not as dependent as HMOs on maintaining any minimum share. They thus would seem to have much less incentive and to be in a much weaker position to engage in potentially costly anticompetitive acts. See Havighurst, HMOs 771. 
1. The Showing of Market Power. In many instances successful antitrust attacks on restrictive insurance company behavior toward HMOs will have to establish that the behavior constitutes monopolization or an attempt to monopolize, both of which are prohibited by section 2 of the Sherman Act. ${ }^{181}$ A necessary element of monopolization is proof of the defendant's monopoly power. ${ }^{182}$ This term has been defined by the Supreme Court as "the power to exclude competition," 183 a more precise restatement of which might be "a substantial degree of power to exclude competitors by reducing price, and still be profitable."184

Proof that a defendant has some degree of market power may be important and often necessary in establishing an attempt to monopolize. The existence of market power can help characterize particular conduct (for example, price discrimination or exclusive dealing) as conduct from which one may infer a specific intent to monopolize, ${ }^{185}$ the minimally essential element in proving attempts. ${ }^{186} \mathrm{~A}$ showing that the defendant possesses some market power will be necessary where the antitrust court requires, as a second element, that there be some "dangerous probability" that monopoly power would have been achieved had the attempt succeeded. ${ }^{187}$

Proof of market power in section 2 cases typically involves a twopart analysis, which consists of defining the relevant market and assessing a party's power within that market in terms of relative market shares, the relative strengths and weaknesses of competitors, barriers to entry, and other structural, conduct and performance evidence. ${ }^{188}$ Several observations about health insurance markets are relevant in applying this analysis to antitrust litigation designed to protect HMOs from unfair behavior.

181. 15 U.S.C. $\$ 2$ (1976).

182. See, e.g., United States v. Aluminum Co. of America, 148 F.2d 416, 422-32 (2d Cir. 1945); United States v. United Shoe Mach. Corp., 110 F. Supp. 295, 342-45 (D. Mass. 1953), affd per curiam, 347 U.S. 521 (1954).

183. United States v. Griffith, 334 U.S. 100, 107 (1948).

184. L. Sullivan $\$ 22$ (emphasis supplied). See Turner, Antitrust Policy and the Cellophane Case, 70 HaRv. L. Rev. 281, 302 (1956).

185. See L. Sullivan $§ 15(a)$.

186. See id. $\S \S 50-52$.

187. Several circuit courts have required this second element. See P. AREEDA, supra note 115, at I 273(b) n.83. The Ninth Circuit is an apparent major exception. See Lessig v. Tidewater Oil Co., 327 F.2d 459, 474 (9th Cir.), cert. denied, 377 U.S. 993 (1964). On the academic debate over whether this second requirement to prove an attempt is justified, compare L. SuLLIVAN II 51(b) \& 52 and Turner, supra note 184, at 305, with Cooper, Attempts and Monopolization: $A$ Mildly Expansionary Answer to the Prophylactic Riddle of Section Two, 72 Mich. L. Rev. 373 (1973).

188. See L. Sullivan $\S \S 12-32$. 
First, assuming for a moment that all health insurance is the relevant product market, in many areas of the country Blue Cross and Blue Shield plans do not compete with each other; they sell only hospital and medical insurance respectively, and have market shares of fifty percent or more that could be considered sufficient to support findings of monopoly power. ${ }^{189}$ In other areas, typically the western states, the Blues have smaller although still relatively large market shares, and may compete with each other in the sale of comprehensive hospitaland-medical insurance. ${ }^{190}$ In most instances, however, their competitors have relatively insignificant market shares, ${ }^{191}$ and the Blues often have been successful in differentiating their product from that of competitors through advertising and the development of customer loyalty. ${ }^{192}$ Thus, the Blues often have substantial market power regardless of the size of their shares in a particular market. Moreover, the recent but gradual decline in the Blues' share of private health insurance sales ${ }^{193}$ does not necessarily negate the existence of substantial market power. As Professor Posner notes, ${ }^{194}$ a monopoly price creates incentives for new sellers to enter, and the monopolist may choose to maintain its price and suffer a decline in its market share as the best means of obtaining some monopoly profits. The nonprofit Blues do not, of course, obtain monopoly profits directly in an easily measurable form; their monopoly "profits" occur in the form of excess administrative and provider costs, and perhaps in the subsidization of some subscribers under community rating plans. ${ }^{195}$

Second, the assumption that all health insurance sales constitute the relevant product market may not be valid. Commercial health insurers were excluded from the definition of the relevant product market in Group Health Cooperative v. King County Medical Society. ${ }^{196}$ Such exlusion often may be appropriate in view of supply and demand considerations, which suggest that commercial insurers frequently do not

189. See, e.g., FTC REPORT 52, 60-62, 66. On the size of relative market shares that courts traditionally have required to support findings of monopoly power, see United States v. Aluminum Co. of America, $148 \mathrm{~F} .2 \mathrm{~d} 416,424$ (2d Cir. 1945) ("it is doubtful whether sixty or sixty-four percent would be enough") and L. SULIIVAN $\$ 22$.

190. See, e.g., FTC REPORT 72, 84, 91.

191. See id. 14.

192. See, e.g., S. LAw, supra note 74 , at 111 n.614.

193. See id. 11.

194. See R. PosNeR, supra note 19 , at 215.

195. Initially, community rating for all subscribers, as opposed to separate rates based on the health cost experiences of different groups, was an essential feature of the Blue plans, but today the Blues have moved to greater use of experience rating as a competitive response to commerical insurers. See FTC REPORT 15; S. LAW, supra note 74, at 11-12.

196. 39 Wash. 2d 586, 637-38, 237 P.2d 737, 764-65 (1951). 
compete effectively with provider reimbursement plans like the Blues and HMOs. On the supply side, commercial insurers, which typically offer subscriber indemnity plans, lack an ability to compete by implementing cost reductions through systematic provider controls. ${ }^{197}$ In terms of demand, commercial insurers may attract a different class of subscribers because of their restricted benefits, more liberal use of deduction and copayment provisions and substantially lower premiums. ${ }^{198}$ Even if this alternative market definition is not accepted, these arguments still serve to strengthen any showing of the Blues' market power in a more broadly defined market.

Another consideration in establishing a defendant's market power in HMO cases may be the barriers to HMO entry that exist under federal and state HMO laws and the certificate-of-need provisions of the Health Planning and Resources Development Act. ${ }^{199}$ These barriers restrict only some entrants into health insurance markets, but they are significant because they restrict those that potentially are most efficient. $^{200}$

2. Refusals to Deal. Blue Shield and Blue Cross plans may restrain HMO development by refusing to enter into certain vertical relationships with HMOs or their physicians. Blue Shield plans at times have refused to reimburse part-time HMO physicians for services provided to their fee-for-service patients who are Blue Shield subscribers. ${ }^{201}$ Where Blue Shield provides medical insurance for a relatively substantial portion of such patients, this refusal to deal may dampen the incentive of physicians to work for HMOs, thereby increasing barriers to HMO entry. Blue Cross plans at times have refused to provide new or prospective HMOs with reinsurance, marketing and administrative services at a reasonable price. ${ }^{202}$ In some instances these services can also be obtained from commercial health insurers, ${ }^{203}$ but Blue Cross provision of the services may have particular value to HMOs because of lower costs, Blue Cross' greater penetration of and experience in a particular market and the attractiveness to consumers of Blue

197. FTC REPORT 16.

198. See M. ROEMER, supra note 10 , at $14-17$.

199. Barriers to HMO entry under federal and state HMO laws are discussed in notes $47-48$ supra. The Health Planning and Resources Development Act and the possibility of undue barriers to HMO entry thereunder are discussed in the text at notes 297-308 infra.

200. See text accompanying notes 9-15 supra.

201. See Group Health Coop. v. King County Medical Soc'y, 39 Wash. 2d 586, 596-98, 237 P.2d 737, 744-45 (1951); Medical Serv. Corp., [1976] 3 TRADE REG. REP. (CCH) I 21,195 (FTC Consent Order, Sept. 15, 1976).

202. See FTC REPORT 40, 47; S. LAW, supra note 74, at 110-11.

203. See FTC REPORT 47; Havighurst, HMOs 790. 
Cross hospital insurance as part of their HMO policy. ${ }^{204}$ Thus Blue Cross refusals to deal also may increase barriers to HMO entry.

Blue Shield's denial of coverage to part-time HMO physicians is subject to attack on alternative grounds either as a restraint of trade or as monopolizing behavior. There are only two plausible explanations for this conduct. First, Blue Shield might have entered into a combination with its participating fee-for-service physicians to protect them from HMO competition, a group boycott that is clearly illegal under section 1 of the Sherman Act. ${ }^{205}$ Second, absent any evidence of combination, Blue Shield's behavior as an independent firm, resulting in more limited services to its subscribers, seems explicable only as conduct by a powerful firm that is aimed at excluding competitors. In this situation Blue Shield may be characterized as a firm with substantial market power over a relatively unique resource (financing patient bills) which it provides to some physicians but not to those who represent a competitive threat to Blue Shield itself. Section 2 of the Sherman Act imposes an obligation upon such monopolists to deal with their competitors. $^{206}$ Therefore, a section 2 analysis will falter only if Blue Shield's market share is not large enough to support a finding of monopoly power and the antitrust court insists upon a showing that monopoly power would have resulted from a successful attempt in order to establish an "attempt to monopolize" violation. ${ }^{207}$

Blue Cross refusals to deal with HMOs present a more difficult antitrust issue if the services desired by an HMO are not provided to others at an established market price. A monopolist's obligation to serve competitors under section 2 has not been extended to cover this situation. ${ }^{208}$ Judicial reluctance to interfere with a business firm's judgment ${ }^{209}$ and judicial unwillingness to engage in direct public utility regulation to determine a "reasonable" price 210 appear sound reasons for rejecting such an extension. Moreover, unlike the case of a monopoly hospital that discriminates in prices charged to non-hospital-based HMOs, ${ }^{211}$ HMOs probably can obtain these services from commercial health insurers, albeit at some higher price.

In some areas Blue Cross may be selling reinsurance, marketing

204. See S. LAW, supra note 74, at 110; Eilers, The Implications of HMOs for Private Insurers, 10 INQUIRY, Mar. 1973, at 59-63.

205. 15 U.S.C. $\$ 1$ (1976). See text accompanying notes 77-81 supra.

206. See Otter Tail Power Co. v. United States, 410 U.S. 366 (1973); United States v. Terminal R.R. Ass'n, 224 U.S. 383 (1912).

207. See note 187 supra and accompanying text.

208. See generally L. Sullivan \& 48; Cooper, supra note 187 , at $440-43$.

209. See Cooper, supra note 187, at 440-41.

210. See generally L. Sullivan $\$ \S 47-48$. See text accompanying notes 146-49 supra.

211. See text accompanying notes $146-49$ supra. 
and administrative services to other, more friendly, HMOs, ${ }^{212}$ and in many states Blue Cross hospital insurance rates are subject to regulation by state insurance departments. ${ }^{213}$ In these situations, if Blue Cross can be shown to have monopoly power, HMOs should have a right under section 2 of the Sherman Act to obtain Blue Cross services on a nondiscriminatory or reasonable basis. ${ }^{214}$

3. Anticompetitive Pricing. The Blues and defensive HMOs might engage in a variety of pricing practices designed to deter entry or discourage aggressive competition by other HMOs. Such practices include exclusive dealing, where the insurer offers a group contract to an employer or union only on condition that a certain percentage of employees or members elect to be covered by the contract, ${ }^{215}$ and price discrimination, where customers sought by competitor HMOs are offered lower prices than other customers. ${ }^{216}$ Also included are belowcost (predatory) pricing or promotion ${ }^{217}$ and "entry limiting" pricing, in which prices are lowered below the short-run profit-maximizing level in an effort to discourage entry by HMOs. ${ }^{218}$ These practices may be attacked under section 2 as monopolizing conduct and, in some cases, also under section 1 as a restraint of trade.

Exclusive dealing contracts with customers, price discrimination that favors certain customers and predatory pricing or promotion all may constitute monopolizing conduct by a firm with substantial market power. ${ }^{219}$ Each of these charges, however, involves substantial problems of proof in distinguishing between behavior that is exclusionary in intent or effect and behavior that is legitimately competitive. ${ }^{220}$ These problems may be even more difficult in antitrust cases against insurance companies because it will be necessary to show that the prices or coverage conditions on group contracts offered to particular groups are, as an actuarial matter, not related to the expected health care costs of the group to be covered.

Tackling this problem, however, could be worth the effort, given particular incentives that state-wide Blue Cross/Blue Shield programs

212. See text accompanying notes $18-19$ supra.

213. See S. LAw, supra note 74 , at $13-18$.

214. See Otter Tail Power Co. v. United States, 410 U.S. 366 (1973); Associated Press v. United States, 316 U.S. 1 (1945); United States v. Terminal R.R. Ass'n, 224 U.S. 383 (1912).

215. See Havighurst, HMOs 774; Schneider, Model Consumer Health Maintenance Organization Act and Commentary, 6 RUT-CAM. L. REv. 266, 287 n.55 (1974).

216. See Schneider, supra note 215, at 287 n.55.

217. Id.

218. See Havighurst, HMOs 772.

219. For citations to the relevant case law, see Cooper, supra note 187, at $435-40,445-48$.

220. See L. Sullivan $\S \S 47,163-168$. See generally Areeda \& Turner, supra note 19. 
or relatively large medical care foundations (MCFs) ${ }^{221}$ may have for engaging in these practices. The position of these plans vis-à-vis individual HMOs attempting to enter particular communities seems to satisfy the theoretical conditions for cost-effective and thus desirable predatory behavior by a monopolist. Predatory activities by a monopolist generally should be relatively infrequent because of the cost of such activities to the monopolist, even where the monopolist has relatively greater resources than its competitors. A large, multi-market health insurance plan, however, may be able to engage in relatively inexpensive predation against HMOs. It may do so if it can establish a credible "threat" of predation in all its markets by engaging in costly predatory practices in a few selected markets that HMOs initially try to enter. ${ }^{222}$

The unique position of Blue Cross in negotiating for Blue Cross subscriber rates at hospitals also may produce an indirect form of predatory pricing that disadvantages HMOs. As described above, ${ }^{223}$ these negotiations may shift some Blue Cross "costs" onto other hospital feepaying patients. This would result in "below-cost" Blue Cross insurance premiums and unfairly high costs to non-hospital-based HMOs. The major substantive problem with attacking this form of anticompetitive pricing may be the difficulty in proving bad purposes or harmful effects. The Blue Cross program to obtain discounts is likely to have been engaged in as part of an overall "cost control" effort by Blue Cross and to cover a fairly broad geographical area, making it difficult to prove harmful purposes or effects. ${ }^{224}$

Since exclusive dealing with customers involves an agreement between seller and buyer, such behavior that adversely affects HMOs also may be attacked as a restraint of trade. ${ }^{225}$ Price discrimination and predatory pricing against HMOs by medical society-sponsored MCFs (or Blue Shield organizations controlled by physicians) could be attacked similarly if an agreement among physician sponsors to engage in such acts can be established. Formally, restraint of trade analysis would obviate the need to prove the existence of a defendant's monopoly or near-monopoly power, although a showing of substantial market

221. MCFs, which are sponsored by state and county medical societies, are described in note 19 supra.

222. See R. POSNER, supra note 19 , at 223-25.

223. See text accompanying notes 130-34 supra.

224. See Travelers Ins. Co. v. Blue Cross, 481 F.2d 80, 94 (3d Cir.), cert. denied, 414 U.S. 1093 (1973). Of course, an HMO, with its subscriber enrollment concentrated in one geographic area, may be in a better position than a commercial insurer to show harmful effects from a Blue Cross discount.

225. See FTC v. Motion Picture Advertising Serv. Co., 344 U.S. 392 (1953). 
power still may help to establish the harmful effects or purposes of these alleged restraints. ${ }^{226}$

Finally, the Blues or defensive HMOs might employ entry limiting pricing against independent HMOs, but it is questionable whether the Sherman Act would be applied to prohibit such behavior. It has been argued that limit pricing by a monopolist "has the explicit purpose and likely effect of inhibiting entry" and may leave "traces discernible to discovery processes."227 Limit pricing by MCFs or Blue Shield plans controlled by physicians also can be compared to maximum price fixing agreements by competitors, ${ }^{228}$ which generally are considered to be per se illegal because of their entry limiting effect as well as their potential for disguising minimum price fixing agreements. ${ }^{229}$ There are, however, some persuasive reasons for not applying the Sherman Act to such instances of limit pricing. Professors Areeda and Turner point out that limit pricing represents "competition on the merits" because it excludes only relatively inefficient entrants whose costs are above the limit price. ${ }^{230}$ In addition, limit pricing by MCFs may be viewed as an essential part of a legitimate joint venture among physicians to control escalating costs. ${ }^{231}$ These reasons, as well as the considerable practical difficulties in administering a prohibitory rule, would appear to be relatively strong justification for not applying the Sherman Act to ban limit pricing against HMOs.

4. Defensive HMOs: Monopolization and Joint Venture Issues. The very organization of defensive HMOs by medical societies, the Blues or hospitals in order to deter independent HMOs might be sub-

226. See id. Cf. Tampa Electric Co. v. Nashville Coal Co., 365 U.S. 320 (1961) (emphasizing the importance of a defendant's market power in establishing harmful effects of an exclusive dealing agreement under section 3 of the Clayton Act).

227. L. Sullivan $\S 47(\mathrm{c})$.

228. Havighurst, HMOs 773-76. But see note 231 infra and accompanying text. MCFs, in essence, are combinations of physicians who agree to market a substantial portion of their services to insureds through a joint selling agency and who agree not to charge this agency more than certain maximum fees. See note 19 supra.

229. See Kiefer-Stewart Co. v. Joseph E. Seagram \& Sons, Inc., 340 U.S. 211 (1951); L. SULIIVAN $\$ \$ 77-78$.

230. Areeda \& Tumer, supra note 19, at 705-06.

231. The general legitimacy of using MCFs to control escalating health care costs has been sanctioned by Congress through its endorsement of MCF development under the Health Maintenance Organization Act of 1973. 42 U.S.C. $\S 300 \mathrm{e}-1$ (5) (Supp. v. 1975). A legitimate business purpose for a joint selling agency supports application of a rule of reason analysis rather than a per se rule to just selling agents. See L. Sullivan $\$ 77$. Under a rule of reason approach, the same kinds of arguments that apply to limit pricing by a monopolist would appear to be applicable to limit pricing by MCFs. But see Kallstrom, Health Care Cost Control By Third-Party Payors: Fee Schedules and the Sherman Act, 1978 DukE L.J. 645, 650-81, who does not consider congressional endorsement of MCFs in his analysis. 
jected to two types of antitrust analysis. ${ }^{232}$ First, where the sponsor of the defensive HMO possesses substantial market power, the organization of the HMO might be characterized as exclusionary conduct by a monopolist that is analogous to the "fighting ship" or "fighting brand" tactics that have been employed in other industries to insulate the predator's established product from the higher costs of general predatory pricing. ${ }^{233}$ The essential difficulty with this approach lies with the problem of distinguishing anticompetitive HMO formation by fee-forservice institutions from the development of better products and the advisability of applying the Sherman Act to ban development of better products by a monopolist. Blue plans and hospitals that sponsor HMOs can claim quite easily that their HMOs are intended to improve the efficiency of their operations and to offer the public a better product. ${ }^{234}$ Any exclusionary effect on other HMOs, according to this argument, should be considered merely an incidental side effect of competition on the merits.

Second, where the defensive HMO is an MCF or is operated as a combination of health insurer or hospital and some significant group of physicians, the organization of the HMO might be characterized as a "joint venture" that is designed to limit actual or potential competition and therefore subject to section 1 as well as section 2 of the Sherman Act. ${ }^{235}$ In addition to exclusion of more independent, aggressive HMOs, anticompetitive restraints that might be caused by these joint ventures include limitation of previous competition among competitors (as with the formation of MCFs by fee-for-service physicians), ${ }^{236}$ the foreclosure of the joint venture's parents entering their own more independent HMOs into the insurance market, ${ }^{237}$ and restraint of competition between the joint venture HMO and either or both of its

232. The basic nature of defensive HMOs is described in note 19 supra. For more extensive discussion of the issues noted in this section, see Competition in the Health Services Market, supra note 25, at 1069-85 (statement of Clark C. Havighurst); Havighurst, HMOs 766-77; Havighurst, supra note 4 , at $257-62$.

233. See Federal Maritime Board v. Isbrandtsen, Inc., 356 U.S. 481 , 488 (1958); Patterson v. United States, 222 F. 599, 612-13 (6th Cir.), cert. denied, 238 U.S. 635 (1915); Cooper, supra note 187, at 446 n. 269.

234. Both the Blues and hospitals might analogize their formation of HMOs to "vertical integration forward": the Blues into the business of providing services, and hospitals into the business of providing comprehensive inpatient and outpatient services. Such internal expansion generally has been assumed to be legal. See United States v. Arnold, Schwinn \& Co., 388 U.S. 365, 379-80 (1967); Standard Oil Co. of Calif. v. United States, 337 U.S. 293, 315-21 (1949) (dissenting opinion).

235. See generally Pitofsky, Joint Ventures Under the Antitnust Laws: Some Reflections on the Significance of Penn-Olin, 82 HARv. L. REv. 1007 (1969).

236. Havighurst, HMOs 774. See notes 228-29 supra and accompanying text.

237. See United States v. Penn-Olin Chem. Co., 378 U.S. 158 (1964). 
parents. ${ }^{238}$ These additional restraints which may be present with joint venture defensive HMOs suggest that joint venture analysis under Section 1 may be a much more fruitful line of inquiry in this area than monopolization analysis under Section 2.

5. The McCarran-Ferguson Exemption. The McCarran-Ferguson Act's partial exemption from federal antitrust law for state regulated insurance activities ${ }^{239}$ may protect much anticompetitive behavior by insurance companies. The relative breadth of the exemption ${ }^{240}$ and the widespread nature of state regulation of health insurance ${ }^{241}$ indicate that anticompetitive pricing by insurers against HMOs and the organization and operation of defensive HMOs may be exempt from federal antitrust scrutiny in most instances. On the other hand, Blue plan refusals to deal with HMOs or their physicians and certain types of exclusive dealing contracts may not be protected.

The McCarran-Ferguson Act limits the application of federal antitrust law "to the business of insurance to the extent that such business is not regulated by State law," 242 with the important exception that the Sherman Act remains applicable to any agreement or act of "boycott, coercion, or intimidation." 243 In the absence of further definition of these terms by Congress, ${ }^{244}$ they have been the subject of some interesting judicial interpretations that will be of critical importance in antitrust litigation designed to protect HMOs from anticompetitive behavior by other insurers.

In SEC v. National Securities, Inc. ${ }^{245}$ the Supreme Court provided a general definition of "the business of insurance." This definition requires that an insurance company activity be part of or closely related to the "relationship between insurer and insured," in other words, that it relate to the company's "status as [a] reliable insurer."246 This limiting definition has been used to exclude from "the business of insurance" such activities as the provision of information to prospective

238. Havighurst, HMOs 777. See United States v. Pan Am. World Airways, Inc., 193 F. Supp. 18 (S.D.N.Y. 1961), rev'd on other grounds, 371 U.S. 296 (1963).

239. 15 U.S.C. $\$ \$ 1011-1015$ (1976).

240. See generally Note, The McCarran-Ferguson Act: A Time for Procompetitive Reform, 29 VAND. L. REV. 1271, 1277-86 (1976).

241. See Hanson, The Private Insurance Industry and State Insurance Regulatory Activities as Alternatives to Federally Enacted Comprehensive National Health Insurance Legislation, 6 U. ToLEDO L. REV. 677, 695-713 (1975).

242. 15 U.S.C. $\$ 1012(\mathrm{~b})(1976)$.

243. Id. $\S 1013(\mathrm{~b})$.

244. See Note, supra note 240 , at 1277 .

245. 393 U.S. 453 (1969).

246. Id. at 460 . 
shareholders, ${ }^{247}$ a merger between two interstate insurance companies $^{248}$ and the sale of goods not closely related to the sale of insurance. ${ }^{249}$ Direct interference with another insurance company's operations ${ }^{250}$ and an insurer's purchase of goods not closely related to the insurer-insured relationship ${ }^{251}$ also have not qualified for the exemption. . $^{25}$

The McCarran-Ferguson provision that the challenged insurance company activity must be "regulated by State law" has been interpreted quite liberally. ${ }^{253}$ The most general sorts of standards

247. Id.

248. See American Gen. Ins. Co. v. FTC, 359 F. Supp. 887, 896-97 (S.D. Tex. 1973), affd, 496 F.2d 197 (5th Cir. 1974).

249. See SEC v. Variable Annuity Life Ins. Co. of America, 259 U.S. 65 (1959). Compare Fry v. John Hancock Mutual Life Ins. Co., 355 F. Supp. 1151 (N.D. Tex. 1973) (tie of insurance sales to loans was "only incidental" to loan agreements to which antitrust laws could apply) with Addrisi v. Equitable Life Assurance Soc'y of the United States, 503 F.2d 725, 728 (9th Cir. 1974), cert. denied, 420 U.S. 929 (1975) (tie of insurance sales to loans was part of the "business of insurance") and Commander Leasing Co. v. Transamerica Title Ins. Co., 477 F.2d 77 (10th Cir. 1973) (sale of an abstract of title together with title insurance is all part of the "business of insurance"). See generally Comment, The McCarran Act's Antitrust Exemption for "the Business of Insurance": A Shrinking Umbrella, 43 TENN. L. REv. 329, 341-58 (1976).

250. See American Family Life Assurance Co. v. Planned Marketing Assocs., 389 F. Supp. 1141, 1146 (E.D. Va. 1974).

251. See Hill v. National Auto Glass Co., 293 F. Supp. 295 (N.D. Cal. 1971).

252. Significantly, three circuit court decisions have split over the issue of whether an insurer's purchase of goods or services are within "the business of insurance" when the cost of such purchases is a substantial part of the insurance premium. Compare Proctor v. State Farm Mutual Auto. Ins. Co., 561 F.2d 262 (D.C. Cir. 1977), petition for cert. filed, 46 U.S.L.W. 3375 (U.S. Oct. 19,1977 ) (No. 77-580) (purchase of automobile repair services are part of the business of insurance) and Travelers Ins. Co. v. Blue Cross, 481 F.2d 80, $82-83$ (3d Cir.), cert. denied, 414 U.S. 1093 (1973) (Blue Cross purchase of hospital services are part of the business of insurance) with Royal Drug Co. v. Group Life \& Health Ins. Co., 556 F.2d 1375 (5th Cir. 1977) cert. granted, 46 U.S.L.W. 3541 (U.S. Feb. 28, 1978) (No. 77-952) (Blue Shield's purchases of drugs are not part of the business of insurance). This split could be resolved, perhaps, by noting the presence of fairly extensive state insurance department regulation over the purchase activities in the two cases which held the purchases to be part of the business of insurance. See Travelers, 481 F.2d at 83-84; Proctor, 406 F. Supp. at 30-31. By contrast, insurance department regulation over the insurer's purchase activities in the third case was much less specific and arguably nonexistent. See Royal Drug, 415 F. Supp. at 345-46. In Royal Drug the Fifth Circuit distinguished Travelers on the basis of extensive state regulation over Blue Cross' purchase of hospital services. $556 \mathrm{~F} .2 \mathrm{~d}$ at 1382-83. While the definition of "the business of insurance" under McCarran-Ferguson is a question of federal law, see SEC. v. National Sec., Inc., 393 U.S. 453, 459-61 (1969), it seems appropriate to give weight to a state insurance department's judgment on this matter, particularly in view of Congress' basic intent behind the McCarran-Ferguson Act to support state regulatory activities in the insurance field. The Supreme Court so interpreted Congress' basic intent in Prudential Ins. Co. v. Benjamin, 328 U.S. 408, 429 (1946). See also text accompanying notes 253-63 supra. For a more detailed discussion and different analysis of this issue concerning an insurer's purchase of goods or services, see Weller, The McCarran-Ferguson Act's Antitrust Exemption For Insurance: Language, History and Policy, 1978 .DUKE L.J. 587.

253. See Note, supra note 240 , at $1284-85$. 
governing the insurance business ${ }^{254}$ and the mere authorization of regulation by statute rather than effective regulation ${ }^{255}$ have been held to satisfy this condition. In a leading recent case, Ohio AFL-CIO v. Insurance Rating Board, ${ }^{256}$ the Sixth Circuit stated the test to be "whether the state has 'generally authorized or permitted certain standards of conduct." "257 Moreover, the state regulatory statute that triggers the McCarran-Ferguson exemption may be other than an insurance statute ${ }^{258}$ and, in any event, the regulatory statute need not contain prohibitions or remedies similar to those in federal antitrust laws. ${ }^{259}$

At first glance, the liberal interpretation of "state regulation" may appear inconsistent with recent judicial narrowing of the "business of insurance" term. ${ }^{260}$ The inconsistency disappears, however, when one considers the two-part rationale that seems to have motivated Congress in passing the McCarran-Ferguson Act. One part of the rationale is that insurers may need an exemption from antitrust laws to engage in activities such as price-fixing, loss pooling, reinsurance and information exchanges that can help maintain their financial solvency and status as "reliable insurers." 261 This justifies limiting the exemption to insurance company activities closely related to ratemaking and other insurer-insured relationships. The other part of the Act's rationale is that the states should have discretion to determine whether an antitrust exemption should be established. Apparently, this discretion was granted because of the states' proximity to the insurance industry's problems and their prior experience in regulating the industry. ${ }^{262}$ This reasoning, together with Congress' failure to specify standards for the kind of state regulation that triggers the exemption, suggests that Congress also intended to leave states with discretion to determine the na-

254. See, e.g., FTC v. National Cas. Co., 357 U.S. 560, 564-65 (1958).

255. See id;; Ohio AFL-CIO v. Insurance Rating Bd., 451 F.2d 1178 (6th Cir. 1971), cert. denied, 409 U.S. 917 (1972).

256. 451 F.2d 1178 (6th Cir. 1971), cert. denied, 409 U.S. 917 (1972).

257. Id. at 1182 (quoting California League of Independent Producers v. Aetna Cas. \& Sur. Co., 175 F. Supp. 857, 860 (N.D. Cal. 1959)) (emphasis added). See also Ohio v. Ohio Medical Indem., Inc. [1976-2] TRADE CASES (CCH) II 61,128 (S.D. Ohio, Sept. 16, 1976).

258. See, e.g., Steingart v. Equitable Life Assurance Soc'y of the United States, 366 F. Supp. 790 (S.D.N.Y. 1973) (state antitrust Iaw, if applicable to insurance industry, may trigger McCarran-Ferguson Act). But see Ohio v. Ohio Medical Indem., Inc. [1976-2] TRADE CASES (CCH) I 61,128, at 70,113 n.1 (S.D. Ohio, Sept. 16, 1976).

259. See Prudential Ins. Co. v. Benjamin, 328 U.S. 408, 431 (1946); Transnational Ins. Co. v. Rusenlund, 261 F. Supp. 12 (D. Ore. 1966).

260. For a discussion of this kind of argument, see Note, supra note 240, at 1284-85.

261. SEC v. National Sec., Inc., 393 U.S. 453, 459-60 (1969). See Comment, supra note 249, at 335-37.

262. See Note, Applications of Federal Antitrust Laws to the Insurance Industry, 46 MrNN. L. REV. 1088, 1094 (1962). 
ture of the regulation, including its degree of effectiveness. ${ }^{263}$

The final condition for McCarran-Ferguson protection is that the challenged activity not be an agreement or act of "boycott, coercion, or intimidation."264 In the face of generally ineffectual state regulation of the insurance industry, ${ }^{265}$ it may be tempting to read this "boycott exception" expansively and apply it to any anticompetitive behavior that contains even remote elements of a boycott. ${ }^{266}$ To do so, however, runs the risk of defeating the Act's basic purpose of giving states broad discretion over insurance regulation. It would seem appropriate then that interpretation of the boycott exception be tempered by consideration of this fundamental purpose.

For example, the district court in Professional \& Business Men's Life Insurance Co. v. Bankers Life $\mathrm{Co}^{267}$ held that a complaint alleging attempts by several insurers to "induce the general public from doing business" with another insurer by means of false advertising stated facts sufficient to show a secondary boycott and thus the court refused to grant a motion to dismiss based on the McCarran-Ferguson Act. ${ }^{268}$ Such reasoning might be extended easily to characterize price discrimination, predatory pricing or any kind of exclusive dealing by insurers as falling within the boycott exception to McCarran-Ferguson. However, such extension would be inappropriate in view of the Act's basic rationale. Pricing activities by insurers clearly are part of the insurer's rate-making function, and to treat these activities under the boycott exception would be to invade the states' discretion to regulate this function.

Significantly, the Third Circuit in Travelers Insurance rejected such a broad reading of the boycott exception. Travelers had claimed that Blue Cross was using reimbursement contracts with participating hospitals to shift some costs from Blue Cross subscribers to other feepaying patients, including those covered by Travelers' policies. ${ }^{269}$ This

263. Concerning the unclear nature of legislative intent on the issue of whether "state regulation" was to mean effective regulation or merely any regulation, see $i d 1096$ n.42. At the end of World War II, when the McCarran-Ferguson Act was passed, it was perhaps not implausible that legislators could believe that relatively unregulated private cartel activities could be in the public interest. After all, our highly productive wartime economy had been fueled in good measure by big business with some aid from relaxed enforcement of antitrust laws. See, e.g., J. BLUM, V WAS FOR VICTORY $117-40$ (1976).

264. 15 U.S.C. $\S 1013$ (b) (1976).

265. See Note, supra note 240 , at $1286-98$.

266. See, e.g., Note, Insurance Regulation and Antitnust Exemptions: McCarran-Ferguson, the Boycott Exception and the Public Interest, 27 RUTGERs L. REv. 140, 158 (1973).

267. 163 F. Supp. 274 (D. Mont. 1958).

268. Id. at $281-83$.

269. See text accompanying notes 132-34 supra. 
behavior may be viewed as an indirect form of predatory pricing by Blue Cross. To avoid the McCarran-Ferguson defense, Travelers argued that Blue Cross had used its market power to "coerce" hospitals into accepting these contracts, with the intended effect of attracting subscribers from commercial plans to Blue Cross. ${ }^{270}$ The Third Circuit, however, held that this situation presented no evidence of boycott, coercion or intimidation because of the "economic inducement" to hospitals to negotiate these contracts in order to keep a maximum number of Blue Cross subscribers using the hospitals' facilities. ${ }^{271}$ This narrower reading of the boycott exception can be reconciled with Professional \& Business Men's Life by the fact that the pricing of hospital services arguably has a closer relationship to an insurer's rate-making function than does advertising. ${ }^{272}$ Nonetheless, Travelers' apparent limitation of the boycott exception also seems more consistent with the basic intent of the McCarran-Ferguson Act to grant states broad discretion in regulating the insurance industry.

The Travelers Insurance decision also helps support distinctions that may be drawn between different kinds of exclusive dealing contracts that health insurers might use to lure customers away from HMOs. In one case, an exclusive dealing contract simply might be offered at a better price (because of larger group coverage and lower administrative costs) than nonexclusive contracts. In this situation there will be a clear "economic inducement" to customers and under the reasoning of the Travelers decision the boycott exception should not apply. In another case, only an exclusive dealing contract may be offered although additional types of contracts might also have been offered by the insurer. In this situation customers may have an "economic inducement" to accept exclusive dealing contracts rather than look elsewhere for insurance, but there is more of an element of bad motive and use of force in this situation. Moreover, this kind of practice was among the acts of "boycott, intimidation, and coercion" that were condemned in United States v. South-Eastern Underwriters Association, ${ }^{273}$ the antitrust case that led to enactment of the McCarran-Ferguson Act. ${ }^{274}$

270. 481 F.2d at 84.

271. Id. Without the contracts Blue Cross would provide only partial reimbursement to hospitals rendering services to Blue Cross subcribers, thereby making the hospitals less attractive. Id. at 84 n. 12 .

272. In a recent case unfair advertising practices by an insurer were held not to be part of "the business of insurance." Center Ins. Agency, Inc. v: Byers, [1976-1] TRADE CASEs (CCH) I 60,940 (N.D. Ill. 1976).

273. 322 U.S. $533,535-36$ (1944).

274. See Note, supra note 240, at 1275-77. 
The extensive nature of state regulation over health insurers suggests that the McCarran-Ferguson defense may be raised frequently to defend anticompetitive behavior by insurers against HMOs. Every state controls the organization (or admission to do business), financial condition and policy forms of all health insurers. ${ }^{275}$ Every state also has some form of unfair trade practices act that applies to all insurers. ${ }^{276}$ Typically, this act enumerates and prohibits a variety of unfair trade practices, including misleading advertising, unreasonable price discrimination and "unfair methods of competition" as determined by administrative action of the insurance department. ${ }^{277}$ Many states regulate Blue Cross, Blue Shield and HMO plans under separate enabling acts, but these statutes generally parallel the insurance law provisions described above. ${ }^{278}$ The most important difference among states' regulation of health insurance lies with the varying degree of rate regulation that is imposed on different kinds of insurers. Enabling statutes for Blue plans ${ }^{279}$ and $\mathrm{HMOs}^{280}$ generally provide for direct regulation of insurance premiums under a "reasonableness" standard. On the other hand, commercial insurers as well as Blue plans and HMOs regulated under general insurance laws typically are not subject to direct rate regulation, although over 20 states do attempt to ensure that benefits provided by these insurers are reasonably related to premiums. ${ }^{281}$

How might this elaborate apparatus of state regulation and the McCarran-Ferguson exemption be applied to the anticompetitive behavior of insurers against the HMOs? First, the refusal of Blue plans to deal with HMOs or their physicians should satisfy the boycott exception to the Act. ${ }^{282}$ Also, exclusion of HMO physicians by Blue Shield plans and Blue Cross refusals to provide marketing or administrative services to HMOs may not fall within the scope of state regulation. Arguably, these restraints are not even part of "the business of insurance." $" 283$

275. See Hanson, supre note 241 , at 697.

276. Id. 698-99.

277. Note, supra note 240 , at 1291. See, e.g., KaN. STaT. $\$ \S 40-2403,-2404,-2406$ (a) (1973).

278. See Hanson, supra note 241, at 698; Kissam \& Johnson, State HMO Laws 35.

279. See S. LAw, supra note 74, at 13-14.

280. See Kissam \& Johnson, State HMO Laws 43-45, 53.

281. Hanson, supra note 241, at 698.

282. Cf. Medical Serv. Corp., [1976] 3 Trade Reg. Rep. (CCH) II 21,195 (FTC Sept. 15, 1976) (consent decree obtained by the FTC against Blue Shield's exclusion of HMO physicians).

283. See id. This certainly seems true if direct management services provided to HMOs are not tied to the sale of reinsurance services. See note 249 supra. A closer question may be presented as to whether Blue Shield's choice of participating physicians is related closely enough to the insurer-insured relationship so as to make it part of "the business of insurance." Certainly a decision to exclude HMO physicians qua HMO physicians would not seem to have any direct adverse effect upon Blue Shield's premium rates. Blue Shield might argue, however, that limiting 
Second, anticompetitive pricing against HMOs by other insurers, including defensive HMOs, should qualify for McCarran-Ferguson protection in most instances. Pricing of insurance policies certainly is part of "the business of insurance." Although state regulation of insurance rates has something of a mixed character, direct rate regulation of the Blues and HMOs typically is provided. These institutions are the most likely offenders as they strive to protect or build substantial market shares in particular communities. ${ }^{284}$ Finally, purchasers of policies from an insurer engaged in anticompetitive pricing will have an "economic inducement" to buy at lower prices; under the Travelers Insurance ruling this incentive should negate any finding of a "boycott" or "coercion" by the insurer with the above noted exception of certain exclusive dealing contracts. ${ }^{285}$

Third, the McCarran-Ferguson exemption would seem applicable to defensive HMOs which are organized with an intent to exclude either other HMOs or potential competition between the parents of a joint venture HMO. The strongest argument against applying the exemption would be that the organization of an HMO is antecedent to the sale of insurance policies and thus not part of "the business of insurance." This argument draws some support from National Securities $^{286}$ and American General Insurance Co. v. FTC, ${ }^{287}$ which held, respectively, that the provision of information to prospective shareholders and a merger between two interstate insurance companies were not part of "the business of insurance." This argument is weakened, however, by the fact that the merger activities in those cases did not in and of themselves increase the supply of insurance services. The formation of a defensive HMO would increase the supply of services, and this suggests a close similarity between HMO formation and the insurer-insured relationship that the McCarran-Ferguson Act was designed primarily to protect. ${ }^{288}$ The organization of defensive HMOs will be regulated by the states, ${ }^{289}$ and this activity would not seem to satisfy the moderate reading of the boycott exception that has been sug-

the availability of Blue Shield-covered physicians in an area can limit overall costs on the theory that physician supply generates its own demand. See, e.g., Havighurst, supra note 8, at 1156-60 \& n.56. Blue Shield also might argue that its choice of physicians is designed to protect subscribers who rely on Blue Shield participation as an indication of a physician's quality. But neither of these justifications is rationally served by decisions to exclude HMO physicians qua HMO physicians.

284. See text accompanying notes $178-80$ supra.

285. See text accompanying notes 264-74 supra.

286. 393 U.S. 453 (1969).

287. 359 F. Supp. 887 (1973).

288. See SEC v. National Sec., Inc., 393 U.S. 453, 459-60 (1969).

289. See text accompanying notes 275-81 supra. 
gested above. ${ }^{290}$

Finally, the application of McCarran-Ferguson to joint venture HMOs that are restrained from competing with one of their parents may depend on the nature of the restraint. If the restraint consists of a failure to compete with an insurer parent for potential policyholders, the challenged activity would seem to be part of "the business of insurance" and not within the moderately read boycott exception. Arguably, the decision of an HMO not to compete with its insurer parent may not be "regulated" or even "permitted" by the state in a manner that satisfies the third McCarran-Ferguson condition. The state's antitrust law may not apply to the insurance industry, ${ }^{291}$ and the state's unfair trade practices act might be deemed not to apply to this kind of behavior. $^{292}$ It also may be argued that neither of these types of laws were intended by Congress to displace federal antitrust law with which they are generally consistent, ${ }^{293}$ although this argument seems more persuasive with respect to state antitrust laws that are not intended to apply specifically to the insurance industry and are not administered by the state insurance department. However, even under these different situations a joint venture HMO might argue successfully that its decision not to compete was justified by considerations of financial soundness, a matter which clearly is subject to state insurance regulation.

A different situation will exist if the restraining parent is a medical society and the restraint consists of decisions by the HMO to avoid cost effective medical decisions such as selectivity in choosing specialists or the use of paraprofessionals. These restraints would appear to be neither the business of insurance ${ }^{294}$ nor subject to state regulation, and thus the McCarran-Ferguson exemption should not apply to this case. $^{295}$

290. See text accompanying notes $264-74$ supra.

291. See note 295 infra.

292. On the extreme fuzziness of states' unfair trade practices acts, see text accompanying notes 276-77 supra.

293. See Weller, supra note 252.

294. The purchase or provision of medical services by an HMO is similar to the purchase of hospital services by Blue Cross that was held to be part of the "business of insurance" in Travelers Ins. Co. v. Blue Cross, 481 F.2d 80 (3d Cir.), cert. denied, 414 U.S. 1093 (1973). The arguable differences between these two activities are the fact that the purchase or provision of medical services will have less of a substantial impact on premium rates, see id. at 82-83, and the fact that "anticompetitive" provision of such services by a defensive HMO will in fact increase rather than decrease premiums.

295. It should be noted that state antitrust law may be available in some cases as a technique to avoid the McCarran-Ferguson exemption. See note 258 supra. However, statutory exemptions from state antitrust laws frequently parallel federal exemptions. See Rubin, Rethinking State Antitrust Enforcement, 26 U. FLA. L. REv. 563, 614 (1974). For an application of Washington's "little McCarran-Ferguson Act," see Washington Osteopathic Medical Ass'n v. King County 
6. Primary Jurisdiction and Implied Immunity Defenses. The McCarran-Ferguson exemption generally may be sufficient to protect the organization of defensive HMOs from federal antitrust scrutiny. ${ }^{296}$ In addition, the existence of new federal regulation of HMOs suggests that the "primary jurisdiction" and "implied immunity" doctrines of antitrust law may be relevant to this issue.

A newly organized HMO will need to obtain a certificate-of-need under the relevant provisions of the Health Planning and Resources Development Act of $1974 .{ }^{297}$ It also may seek to qualify for benefits provided to federally qualified HMOs under the Health Maintenance Organization Act of 1973.298 These federal statutes establish "entry" controls over HMOs ostensibly in order to promote both cost and quality of care reforms in the health care system. The former act and its certificate-of-need provisions are designed to promote more efficient methods of health care delivery, to prevent wasteful duplication of facilities, and, significantly, to improve the supply and distribution of health care resources in underserved areas. ${ }^{299}$ Similarly, the Health Maintenance Organization Act is designed to promote HMOs not only as a competitive force in the health market but also as a vehicle for improving distribution of resources and providing more comprehensive health insurance coverage to the public. ${ }^{300}$

Under these statutes defensive HMOs could be approved by regulatory agencies in order to promote statutory objectives that are inconsistent with antitrust policy in a particular case. The existence of these alternative regulatory tribunals and potentially conflicting statutory objectives suggests that defensive HMOs may be able to raise both primary jurisdiction and implied immunity defenses to antitrust attacks on their organization. The primary jurisdiction defense, which is procedural in nature, would seek to obtain a stay of the antitrust proceedings in order to allow a regulatory agency to assess facts and issues that are relevant to the antitrust case but that are within the agency's special

Medical Soc'y, 78 Wash. 2d 577, 579-80, 478 P.2d 228, 230 (1970). Furthermore, in the absence of an explicit exemption, insurers may be able to argue that they are subject to a pervasive state regulatory scheme that justifies an implied immunity from state antitrust law. Compare the arguments for an implied exemption from federal antitrust law. See generally Handler, Regulation Versus Competition, 44 U. CINN. L. Rev. 191 (1975); Shuman, The Application of the Antitrust Laws to Regulated Industries, 44 TENN. L. REv. 1 (1976). See also text accompanying notes 309315 infra.

296. See text accompanying notes 286-90 supra.

297. 42 U.S.C. $\S \S 300 \mathrm{~m}-2(\mathrm{a})(4)(B),-(2)(b)(2), 300 \mathrm{n}-1$ (Supp. V 1975).

298. Id. $\S 300 \mathrm{e}$.

299. See id. $\S 8300 \mathrm{k}, 300 \mathrm{~m}-2(\mathrm{a})(4)(\mathrm{B}), 300 \mathrm{n}-1(\mathrm{c})$.

300. See id. $\$ \S 300 \mathrm{e}$ to 300e-4; Kissam \& Johnson, Federal HMO Laws 1203-12. 
competence..$^{301}$ The implied immunity doctrine is substantive and justifies an exemption from antitrust law for a regulated activity that is in conflict with antitrust policy but "necessary" to promote the objectives of the regulatory statute. ${ }^{302}$

The primary jurisdiction doctrine seems particularly applicable to two kinds of issues that might be raised in an antitrust attack on a defensive $\mathrm{HMO}^{303}$ Plaintiffs might assert either that insurers working with their own peer review panel of physicians would be a less restrictive alternative to $\mathrm{MCFs}^{304}$ or that both parents of a "joint venture" HMO otherwise would be significant potential HMO entrants. ${ }^{305}$ One of the criteria that a certificate-of-need agency uses in assessing entry applications is the "availability of alternative, less costly, or more effective methods of providing such services." ${ }^{306}$ This suggests, in theory at least, that a certificate-of-need agency is a more appropriate forum than an antitrust court to assess the likely availability of less restrictive alternatives or potential entrants. If this argument is sound, ${ }^{307}$ a stay of the antitrust proceedings would be justified to allow for a determination of these issues by the appropriate certificate-of-need agency. A substantive result of this procedural decision might be the effective determination of the antitrust suit by a decision of a certificate-of-need agency that is unduly influenced by fee-for-service interests. ${ }^{308}$

The implied immunity defense to antitrust attacks on defensive HMOs may be even more significant. The argument here is that application of antitrust law to defensive HMOs would defeat the purpose of

301. See Ricci v. Chicago Mercantile Exch., 409 U.S. 289 (1973).

302. See United States v. National Ass'n of Sec. Dealers, 422 U.S. 694, 720-30 (1975); Silver v. New York Stock Exch., 373 U.S. 341, 357 (1963).

303. The primary jurisdiction doctrine usually is, but need not be, asserted prior to a pending or potential regulatory agency decision that will extend to the same activities before the antitrust court. See Ricci v. Chicago Mercantile Exch., 409 U.S. 289 (1973). Many antitrust attacks against defensive HMOs might be brought after the HMO has received its regulatory approvals because of the value of operational evidence, such as limited recruitment of subscribers or a failure to exploit available economics, in proving exclusionary intent or effect. Under the Ricci decision this still would not preclude an antitrust court from referring specific issues to the appropriate certificate-of-need agency.

304. The basic competitive benefit of MCFs, lower costs from peer and utilization review by and of physicians, might be obtained by the less restrictive alternative of independent health insurers working with their own panels of physicians. See Havighurst, HMOs 773-74.

305. In this case, creation of joint venture defensive HMOs may reduce competition in the health insurance market by eliminating the possibility of independent entry of and subsequent competition between the parent HMOs. See generally Pitofsky, supra note 235.

306. 42 U.S.C. \& 300n-1(c)(4) (Supp. V 1975).

307. But see Shuman, supra note 295, at 28-43, who argues that the primary jurisdiction doctrine has been misapplied to antitrust-regulated industry cases and that "[w]ith respect to antitrust issues, agencies possess neither expertise nor superior fact-finding capability. In fact, the courts are institutionally better suited for adjudicating antitrust issues than are the agencies." Id. 39.

308. See Kissam \& Johnson, Federal HMO Laws 1219; Shuman, supra note 295, at 41. 
either or both of the aforementioned statutes, which is to promote various cost and quality of care reforms in a balanced manner. The courts traditionally have relied so much on particular industry facts and regulatory provisions in deciding implied immunity cases ${ }^{309}$ that one veteran observer has described the doctrine as a "tangled skein" and an "impenetrable fog." 310 The lack of precedent relevant to the health care industry makes it difficult to predict how antitrust courts would resolve this issue.

Admittedly, several of the traditional indicia of implied immunity from the antitrust laws are missing in this case. The relevant statutes do not explicitly exempt any health care activities from antitrust law, nor do they expressly direct regulatory agencies to take the antitrust laws into account, although this might be inferred from the certificateof-need criterion quoted above ${ }^{311}$ and the statutes' general emphasis on cost reform. ${ }^{312}$ Additionally, the legislative history of both statutes appears to be silent on the possible application of antitrust law to health services entry. ${ }^{313}$ These considerations may not be decisive, however, in view of the fact that both statutes were enacted before the recent surge of interest in applying antitrust law to the health care industry, and well before the Rex Hospital decision ${ }^{314}$ opened up the specific possibility of applying the Sherman Act to health care entry issues. Moreover, with respect to entry issues, the comprehensive nature of the new federal certificate-of-need law may well satisfy the "pervasive regulatory scheme" test that can justify an implied immunity. ${ }^{315}$

\section{Conclusion}

This Article has surveyed the possible application of antitrust law to a variety of devices that fee-for-service physicians and institutions might employ to restrain the development of HMOs. Antitrust law certainly is useful to protect HMOs from more egregious forms of anticompetitive behavior such as open boycotts against HMO physicians. The body of antitrust law, however, contains a number of relevant defenses that seem capable of protecting unfair behavior toward HMOs

309. See L. Sullivan $\S 239$.

310. See Handler, supra note 162, at 13-14.

311. See text accompanying note 306 supra.

312. See text accompanying notes 299-300 supra.

313. See, e.g., S. REP. No. 1285, 93 d Cong., 2d Sess. (1974) (reporting on S. 2994, the Senate version of the Health Planning and Resources Development Act of 1974); S. REP. No. 129, 93d Cong., 1st Sess. (1973) (reporting on S. 14, the Senate version of the Health Maintenance Organization Act of 1973).

314. 428 U.S. 738 (1976).

315. See United States v. Philadelphia Nat'1 Bank, 384 U.S. 321, 352 (1973). For a discussion of the nature of this test as a slogan, see Handler, supra note 295, at 202. 
in many instances. Moreover, such behavior is possible and perhaps likely in view of the particular nature of professional attitudes among physicians and the complex economic and increasingly regulated nature of the health services industry.

One also may ask whether there are sufficiently strong political, bureaucratic or economic incentives of public antitrust agencies and HMOs to bring antitrust cases in the many difficult areas where such cases may be appropriate. Some health services antitrust litigation, such as that against price-fixing or group boycotts, may be both politically and economically attractive to public agencies and private plaintiffs. These kinds of cases probably are most easily understood by the public as attacks against "evil," and they can serve an important symbolic function for politicians, communicating to the public a concern for its general welfare. ${ }^{316}$ These cases also would seem to be of the type most easily justified on a benefit/cost basis and thus attractive to resource conscious policy planners in public agencies and to potential private plaintiffs.

On the other hand, much antitrust litigation designed to protect HMO interests may have to deal with more difficult and, to the public, less easily understood issues such as restrictive hospital by-laws, NoerrPennington defenses, alleged price discrimination and defensive use of HMOs. With regard to private suits, much of the unfair opposition may be directed at relatively new and smaller HMOs that do not have the economic resources to bring complex antitrust litigation. ${ }^{317}$ Many HMO administrators and physicians also may fear to be connected with such litigation because of the close interrelationships among all sectors of the medical economy and the potential for tarnished reputations from suits against fee-for-service interests. In sum, cautious realism about the value of antitrust law in protecting HMOs from unfair restraints seems to be an appropriate attitude.

In this view, legislative change that effectively promotes HMOs and competitive policies in the health care industry remains significant. Although a relatively long list of desirable changes of this sort is available, ${ }^{318}$ the political power of organized medicine and its fee-for-service allies can be counted on to continue to delay these changes. ${ }^{319}$ It

316. On the symbolic role of antitrust regulation, see M. EDELMAN, THE SYMBOLIC UsES of Politics 22-43 (1964).

317. See Competition in the Health Services Market, supra note 25, at 1584 (statement of John W. Riley).

318. See, e.g., authorities cited in note 8 supra.

319. See, e.g., Iglehart, Intense Lobbying Drive by Medical Group Dims Prospects for HMO Legislation, 1972 NAT'L J. 1404, 1405; Rosoff, Phase Two of the Federal HMO Development Program: New Directions After a Shaky Start, 1 AM. J.L. \& MED. 209, $210-14$ (1975). 
thus may be advisable for HMOs and their allies to adopt a more selective legislative strategy. In this regard, two possible kinds of legislative change may prove attractive. One change would be to repeal the application of the McCarran-Ferguson Act to the health insurance industry, a move which seems eminently justified. ${ }^{320}$ Such a proposal also might obtain support as a result of the current mood for deregulation.

A second priority might be to encourage both federal and state funding of medical school HMOs. These HMOs may not directly be as significant a competitive force as others. ${ }^{321}$ Medical schools, however, seem to be likely sponsors of HMOs, ${ }^{322}$ and such HMOs could serve an important educational purpose in changing the professional attitudes of new generations of physicians. This policy would be consistent, moreover, with the apparently emerging "physician surplus" that promises increased availability of newly trained physicians for new forms of medical practice. ${ }^{323}$

320. It has been argued strongly that the entire McCarran-Ferguson Act should be repealed or at least substantially modified. See, e.g., Note, supra note 240. See also Federal STATE REgULATION OF THE PRICING AND MARKETING OF INSURANCE (P. W. MacAvoy ed. 1977). As strong as these arguments are, however, the case for lifting health insurance from the Act's coverage seems stronger. Quite simply, the Act's basic purpose of protecting horizontal restraints among insurers to help maintain their financial solvency is irrelevant to the health care industry. This sector traditionally has not relied on cooperative rate-making bodies like other sectors of the insurance industry, Hanson, supra note 241 , at 698 , probably because of the different nature of the insurable event, early domination of the industry by the Blues, and the incidental nature of health insurance for multi-service commercial carriers. See J. KRIZAY \& A. WILSON, supra note 19, at 39-40. Repeal of McCarran-Ferguson for health insurance still would leave insurers with a Parker defense in some cases of closely state regulated activities, but under the modern interpretation of Parker, see text at notes 150-77, this would seem to be a better accommodation between regulation and competition concerns.

321. The interest of such an HMO arguably would be educational, rather than economic.

322. See, e.g., Physician Training Facilities and Health Maintenance Organizations: Hearings Before the Subcomm. on Health of the Senate Comm. on Labor and Public Welfare on S. 935, $S$. 703, $S .837, S .1182, S .1301,92$ d Cong., Ist Sess. 483-505 (1971) (statement of Robert M. Heyssel, M.D., executive director, Ass'n of American Medical Colleges).

323. See Katz, Warner \& Whittington, The Supply of Physicians and Physicians' Incomes: Some Projections, 2 J. Health Pol., POL'y \& L. 227 (1977). 
